\title{
Invasion and Dispersal of Biomphalaria Species: Increased Vigilance Needed to Prevent the Introduction and Spread of Schistosomiasis
}

\begin{abstract}
Mohamed R. Habib ${ }^{1,2,3}$, Shan $L^{2,3,4,5,6}$, David Rollinson ${ }^{7}$ and Xiao-Nong Zhou ${ }^{2,3,4,5,6 *}$
${ }^{1}$ Medical Malacology Laboratory, Theodor Bilharz Research Institute, Giza, Egypt, ${ }^{2}$ National Institute of Parasitic Diseases, Chinese Center for Diseases Control and Prevention, Shanghai, China, ${ }^{3}$ Key Laboratory of Parasite and Vector Biology, Ministry of Health, Shanghai, China, ${ }^{4}$ National Center for International Research on Tropical Diseases, Shanghai, China, ${ }^{5}$ WHO Collaborating Center on Tropical Diseases, Shanghai, China, ${ }^{6}$ School of Global Health, Chinese Center for Tropical Diseases Research, Shanghai Jiao Tong University School of Medicine, Shanghai, China, ${ }^{7}$ Department of Life Sciences, Natural History Museum, London, United Kingdom
\end{abstract}

Biological invasion is a matter of great concern from both public health and biodiversity perspectives. Some invasive snail species may trigger disease emergence by acting as intermediate hosts. The geographic distribution of Schistosoma mansoni depends on the presence of susceptible species of Biomphalaria freshwater snails that support the parasite's transformation into infective stages. Biomphalaria spp. have shown strong local and global dispersal capacities that may increase due to the global warming phenomenon and increases in the development of agricultural and water projects. Should intermediate hosts become established in new areas then this will create potential transmission foci. Examples of snail invasions that have had an impact on schistosomiasis transmission include the introduction of Biomphalaria tenagophila to Congo and B. glabrata to Egypt. The current spread of $B$. straminea in China is causing concern and needs to be monitored closely. An understanding of the mode of invasion and distribution of these snails as well as their experimental susceptibility to S. mansoni will predict the potential spread of schistosomiasis. Here we review the invasion patterns of Biomphalaria snails and factors that control their distribution and the impact that invasion may have on intestinal schistosomiasis transmission. In addition, we propose some possible surveillance responses for optimum control strategies and interventions. Whenever possible, swift action should be taken to contain any new occurrence of these intermediate snail hosts.

Keywords: Biomphalaria, invasion, Schistosoma mansoni, schistosomiasis, transmission

\section{BACKGROUND}

Aquatic invasion by exogenous species can cause native biodiversity loss and deleterious environmental and economic impacts (1). Biological invasions of gastropod molluscs have been strongly linked to serious problems to human health. They can cause expansion, emergence, or re-emergence of infectious diseases (2). These risks are anticipated to 
intensify due to ongoing climate change and global warming which continue to create new suitable freshwater environments for snail species serving as disease carriers (3). This review will consider the invasion patterns of Biomphalaria spp. (Class: Gastropoda; Family: Planorbidae) that act as the intermediate hosts for Schistosoma mansoni, a trematode parasite causing intestinal schistosomiasis. Biomphalaria are widely distributed in sub-Saharan Africa, South America, and other subtropical regions. Several species of Biomphalaria have shown strong local or global dispersal capacities. Numerous accidental or deliberate introductions of Biomphalaria spp. have been reported in tropical areas (4). Biomphalaria dispersal is of prime interest because it is often associated with the creation of new transmission foci for schistosomiasis. B. glabrata, B. straminea, B. tenagophila, and $B$. pfeifferi are the most common invasive species that have been introduced into new areas outside their native habitats and acted as potential intermediate hosts for schistosomiasis transmission (5). Therefore, an extensive knowledge of the geographic distribution of susceptible species of Biomphalaria is of considerable importance for the control of schistosomiasis and its epidemiologic surveillance as well as for future delineation of potential risk areas.

\section{GEOGRAPHIC DISTRIBUTION OF SUSCEPTIBLE SPECIES OF BIOMPHALARIA}

The global distribution map of $S$. mansoni is largely defined by the occurrence of Biomphalaria species that are able to transmit the parasite. According to DeJong et al. (6), there are 34 species of Biomphalaria distributed worldwide. Looking back at the long evolutionary history of Biomphalaria spp. it is clear that invasions into new geographical areas have been a regular feature. Molecular evidence suggests that a B. glabrata like taxon, South American in origin, dispersed across the Atlantic to Africa and gave rise to the African species possible quite recently in the PlioPleistocene (1.8-3.6 Myr ago). This West to East transoceanic dispersal could have occurred in the feathers of aquatic birds or on vegetation rafted across the ocean followed by successful colonization (7).

Four Neotropical species act as intermediate host for S. mansoni in the wild, these includes, B. glabrata in Antigua, Brazil, Curacao, Dominica, Guadeloupe, French Guiana, Haiti, Saint Kitts and Nevis, Martinique, Montserrat, Puerto Rico, Dominican Republic, Saint Lucia, Suriname, and Venezuela, B. tenagophila in Southern Brazil, Argentine, Paraguay, Uruguay, Peru, and Bolivia, B. straminea in North-Eastern Brazil, Venezuela, Suriname, French Guiana, Guyana, Peru, Paraguay, Argentine, Dominica, Grenada, Guadeloupe, Martinique, Dominican Republic, Trinidad, Uruguay, and Costa Rica and $B$. prona in Venezuela $(8,9)$. Other species showed susceptibility to experimental infection, but have not been found naturally infected, such as B. amazonica found in Brazil, Bolivia, and Colombia (10), B. havanensis found in Haiti, Mexico, Puerto Rico, Cuba, and Venezuela, B. helophila found in Peru, Cuba,
Costa Rica, Guatemala, Belize, Haiti, Mexico, Saint Thomas, El Salvador, Dominican Republic, Puerto Rico, Barbados, and Nicaragua (11), B. peregrina from Ecuador, Bolivia, Chile, Brazil, Paraguay, Peru, Uruguay, Argentine, and Colombia (12), and $B$. sericea from Ecuador (13). Both susceptible and refractory species may coexist in the same municipality. In São Paulo, in the Southeast Region of Brazil, B. occidentalis, B. oligoza, $B$. peregrina, B. schrammi, B. straminea and B. tenagophila are present in water bodies of the upper basin of the Tietê River (14).

Most African species of Biomphalaria are known as active intermediate hosts of schistosomes in the field (15). Numerous records of natural infections of Biomphalaria with S. mansoni in many African countries are present in literature, examples include B. alexandrina in Egypt $(16,17)$, B. camerunensis in Cameroon (18), B. choanomphala in Tanzania, Kenya, and Uganda (19-21), B. sudanica in Tanzania and Uganda (19, 22), Kenya (23), Ethiopia (24), Burundi (25), and Sudan (26), B. stanleyi in Uganda and Tanzania $(19,22)$, and $B$. pfeifferi, the most important intermediate host for $S$. mansoni in Africa due to its ubiquitous distribution, was found infected in Burundi (25), Cameroon (27), Mali (28), Niger (29), Senegal (30), South Africa (31), Sudan (32), Zimbabwe (33), Tanzania, Uganda (19), and Benin (34). In addition to the geographic areas mentioned above for naturally infected snails, Biomphalaria spp. are widely distributed in many other wetland areas throughout the Americas and Africa (Figure 1 and Table 1).

\section{ECOLOGICAL FACTORS CONTROLLING BIOMPHALARIA ABUNDANCE AND DISTRIBUTION}

Many ecological or environmental factors regulate the distribution and abundance of Biomphalaria spp. The high fecundity of Biomphalaria and their ability to self-reproduce are important traits that support their successful invasion. Adult snails can produce 10,000 eggs per year. The egg-to-egg period requires approximately 11 weeks (127). With a life span of up to one year and a half, Biomphalaria can undergo several generations over a year (128). Following embryonic hatching from egg capsules, Biomphalaria undergo a series of developmental steps leading to maturation and reproduction. The snail has a great capacity to live and reproduce under different environmental conditions $(129,130)$. B. glabrata and B. straminea, for example, were found in 10 of 11 different types of aquatic habitats in Brazil (131).

In natural habitats, Biomphalaria are under the influence of several ecological factors that control the population density of snails although temperature is a key determinant. Detailed review of environmental factors conditioning the habitat of Biomphalaria can be found in Malek (132), Brown (15), and Rollinson (133). In summary, these ecological factors can be divided into biotic and abiotic factors. 


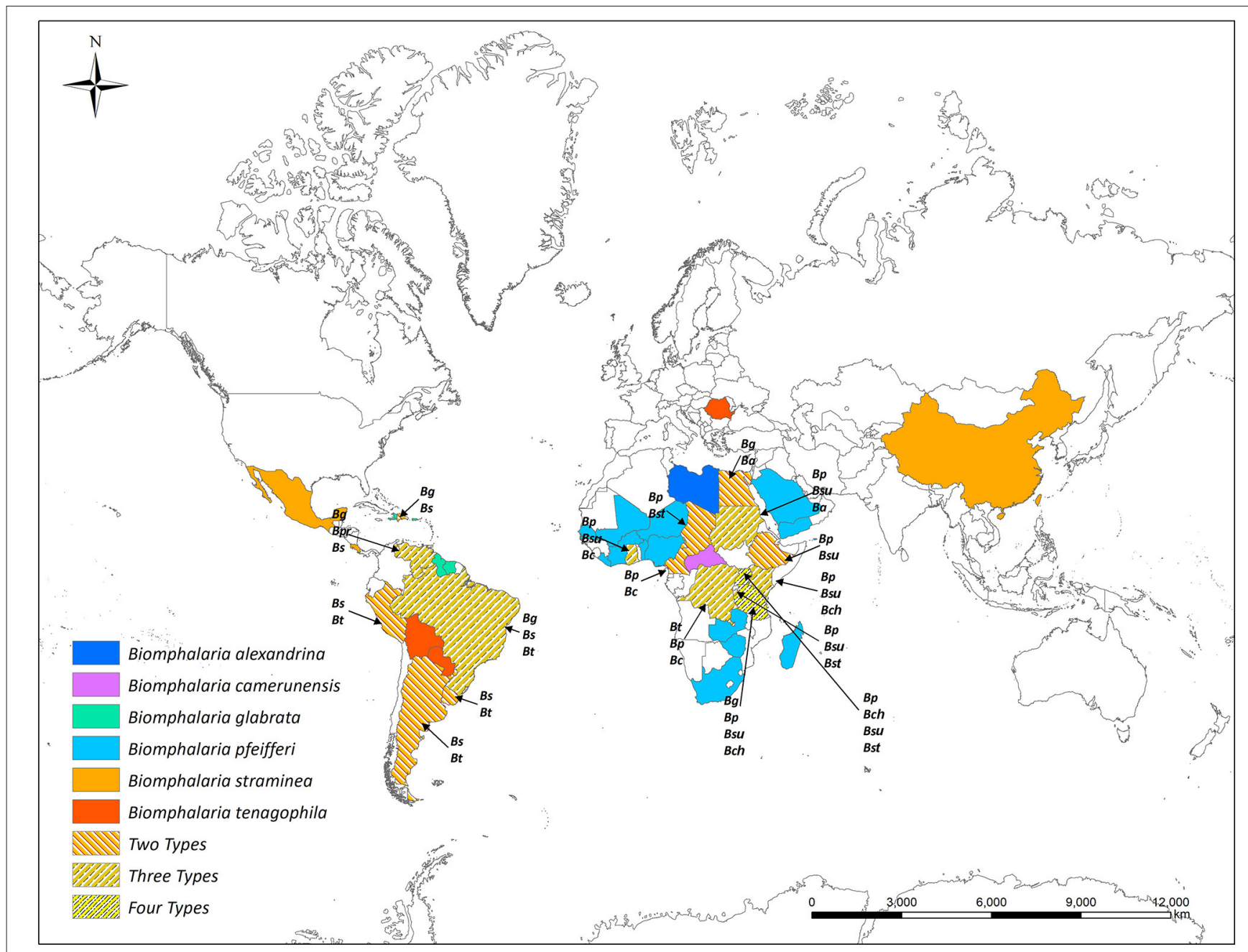

FIGURE 1 | Global distribution of susceptible species of Biomphalaria (country level). Ba, Biomphalaria alexandrina; Bc, Biomphalaria camerunensis; Bch, Biomphalaria choanomphala Bg, Biomphalaria glabrata; Bp, Biomphalaria pfeifferi; Bpr, Biomphalaria prona; Bs, Biomphalaria straminea; Bst, Biomphalaria stanleyi; Bsu, Biomphalaria sudanica; Bt, Biomphalaria tenagophila.

\section{Biotic Factors}

Biotic factors such as plants and food supply have a particular influence on the local abundance and distribution of snails. Predator and competitor species such as other species of snails, fish and insects also control snail populations. Data from field studies in Africa and Brazil indicate that Tilapia fish and some Dipteran insect's larva are predators of Biomphalaria in fishponds and lakes (134). In some cases, the absence of these natural predators may have a detrimental impact on schistosomiasis transmission. For example, the construction Diama Dam on Senegal River Basin obstructed the annual migration of native river prawns, Macrobrachium vollenhoveni, that feed on schistosomes intermediate host snails, leading to massive outbreak of schistosomiasis. Indeed, field experiments showed that reintroduction of the prawns caused a significant reduction in infected snails and human schistosomiasis prevalence $(135,136)$. Moreover, several pilot control studies involving competitor snails, such as Pomacea glauca, Marisa cornuarietis, Melanoides tuberculata, and Helisoma duryi, achieved varying results; characterized mostly by ecological upsets after initial snail reductions $(137,138)$.

\section{Abiotic Factors}

Abiotic factors, such as temperature and water chemistry, can have evident effects on Biomphalaria spp. over short distances within a single waterbody (15). In particular, temperature is important for snail survival and reproduction. Variation in water temperature affects distribution of snails not only from season to season but also from year to year (139). Recent studies on the effects of temperature changes on the growth, fecundity and survival of intermediate host snails of schistosomiasis and schistosomes prevalence indicated that temperature increase may alter the distribution, breeding, growth and survival of snails, and consequently may increase the 
TABLE 1 | Distribution of naturally susceptible species of Biomphalaria.

\begin{tabular}{|c|c|c|}
\hline Species & $\begin{array}{l}\text { Geographic distribution } \\
\text { (Country level) }\end{array}$ & References \\
\hline \multirow{11}{*}{$\begin{array}{l}\text { Biomphalaria } \\
\text { glabrata }\end{array}$} & Brazil $^{\star}$ & $(8,35)$ \\
\hline & French West Indies & $(36,37)$ \\
\hline & West Indian Island of St. Lucia & (38) \\
\hline & Venezuela & $(39,40)$ \\
\hline & Lesser Antilles & (40) \\
\hline & Puerto Rico & (41) \\
\hline & Haiti & (42) \\
\hline & Dominican Republic & $(9,43)$ \\
\hline & Surinam & (9) \\
\hline & French Guiana & (9) \\
\hline & Egypt & $(44-46)$ \\
\hline \multirow{12}{*}{$\begin{array}{l}\text { Biomphalaria } \\
\text { straminea }\end{array}$} & Brazil & $(47-49)$ \\
\hline & Hong Kong & $(50,51)$ \\
\hline & China & $(52-54)$ \\
\hline & French West Indies & (36) \\
\hline & Uruguay & $(55,56)$ \\
\hline & Venezuela* $^{*}$ & $(9,57)$ \\
\hline & Costa Rica & (58) \\
\hline & Argentina & $(59,60)$ \\
\hline & Dominican Republic & $(61,62)$ \\
\hline & Mexico & (63) \\
\hline & Peru & (64) \\
\hline & Dominica & (65) \\
\hline \multirow{8}{*}{$\begin{array}{l}\text { Biomphalaria } \\
\text { tenagophila }\end{array}$} & Romania & (66) \\
\hline & Brazil & $(67-69)$ \\
\hline & Uruguay & $(70,71)$ \\
\hline & Paraguay & (72) \\
\hline & Argentina* $^{*}$ & $(73,74)$ \\
\hline & Peru & $(75)$ \\
\hline & Democratic Republic of Congo & $(9,76)$ \\
\hline & Bolivia & (9) \\
\hline \multirow[t]{16}{*}{ Biomphalaria pfeifferi } & South Africa* & (15) \\
\hline & Ethiopia & $(77-79)$ \\
\hline & Nigeria & $(80,81)$ \\
\hline & Sudan & $(82,83)$ \\
\hline & Saudi Arabia & (84) \\
\hline & Ghana & (85) \\
\hline & Democratic Republic of Congo & $(86,87)$ \\
\hline & Senegal & $(88,89)$ \\
\hline & Kenya & $(90,91)$ \\
\hline & Zimbabwe & (92) \\
\hline & Niger & (93) \\
\hline & Mali & $(94,95)$ \\
\hline & Liberia & $(96,97)$ \\
\hline & Cote-d'Ivoire & $(98)$ \\
\hline & Tanzania & (99) \\
\hline & Benin & (100) \\
\hline
\end{tabular}

(Continued)
TABLE 1 | Continued

\begin{tabular}{|c|c|c|}
\hline Species & $\begin{array}{l}\text { Geographic distribution } \\
\text { (Country level) }\end{array}$ & References \\
\hline & Cameroon & $(101,102)$ \\
\hline & Burundi & $(25)$ \\
\hline & Yemen & (103) \\
\hline & Zambia & $(104,105)$ \\
\hline & Chad & (106) \\
\hline & Uganda & (107) \\
\hline & Madagascar & (15) \\
\hline & Burkina Faso & (108) \\
\hline \multirow{3}{*}{$\begin{array}{l}\text { Biomphalaria } \\
\text { alexandrina }\end{array}$} & Egypt $^{*}$ & $(109-111)$ \\
\hline & Libya & $(112)$ \\
\hline & Sudan & (113) \\
\hline \multirow{7}{*}{$\begin{array}{l}\text { Biomphalaria } \\
\text { sudanica }\end{array}$} & Sudan $^{*}$ & (15) \\
\hline & Tanzania & $(114,115)$ \\
\hline & Kenya & (91) \\
\hline & Uganda & $(19,116)$ \\
\hline & Ghana & $(117)$ \\
\hline & Ethiopia & (118) \\
\hline & Burundi & (25) \\
\hline \multirow{3}{*}{$\begin{array}{l}\text { Biomphalaria } \\
\text { choanomphala }\end{array}$} & Tanzania* & (15) \\
\hline & Uganda & (119) \\
\hline & Kenya & (120) \\
\hline \multirow{5}{*}{$\begin{array}{l}\text { Biomphalaria } \\
\text { camerunensis }\end{array}$} & Cameroon* & (121) \\
\hline & Democratic Republic of Congo & (122) \\
\hline & Ghana & (15) \\
\hline & Central African Republic & (15) \\
\hline & Zaire & $(123)$ \\
\hline Biomphalaria prona & Venezuela* & $(9,124)$ \\
\hline \multirow{4}{*}{$\begin{array}{l}\text { Biomphalaria } \\
\text { stanleyi }\end{array}$} & Tanzania* & $(19,114)$ \\
\hline & Uganda & (22) \\
\hline & Burundi & (125) \\
\hline & Chad & (126) \\
\hline
\end{tabular}

${ }^{*}$ Indicates first record of the species.

spread of schistosomiasis (140-142). In Egypt, high temperatures appear to reduce snail breeding and March is the month of maximal breeding for B. alexandrina (143). Yousif et al. (144) found that $B$. alexandrina populations exhibited two peaks of populations density that differ in heights depending on the extent of water temperature and winter closing. The first peak is from April-May and the second is from November-December. These two peaks are permeated by two lows following the Winter Closure and during the hot summer season. Under laboratory condition, B. alexandrina has optimal growth and egg laying at $26-28^{\circ} \mathrm{C}(145)$. A similar temperature range was also found with B. glabrata (146). Also, a positive correlation was 
observed between $B$. sudanica abundance and water temperature (22). Appleton et al. (147) observed a negative correlation between fecundity and increasing above-optimal temperatures $\left(>27^{\circ} \mathrm{C}\right.$ ) during maturation period of $B$. pfeifferi. The authors concluded that the change in temperature regime is responsible for the species' absence from pans in some areas of SouthEastern Africa due to the sensitivity of $B$. pfeifferi to high temperature. Furthermore, the distribution of $B$. pfeifferi and $B$. sudanica is limited to north and north-eastern parts of Uganda characterized by suitable temperatures (148). Temperatures higher than optimal values cause retardation in the development of gonads and albumen gland and a decrease in egg-production and viability.

Water chemistry is an important factor for snail distribution (149). For example, inorganic salts govern the osmotic properties of the aquatic environment, which in turn are linked to the sensitivity of snail eggs to salinity. Most common ions in natural water include calcium, magnesium, sodium, bicarbonate, carbonate, chlorine, and phosphate. Snails usually prefer environments rich with calcium. The presence of calcium in water is important for snails since it is essential for the construction of the shells (150). Studies on B. pfeifferi showed that the snail is restricted to water with a minimum calcium concentration of $5 \mathrm{mg} / \mathrm{l}$. High ratios of magnesium/calcium and sodium/calcium indicate low bioavailability of calcium and exert a negative impact on the egg production of the snails and can reduce their densities (151). Calcium has been associated with high fecundity of B. glabrata (149). El-Khayat et al. (152) showed that the habitat preferred by $B$. alexandrina snails contained higher concentration of various common ions such as potassium, sodium, and calcium. Also, field studies by Kloos et al. (35) showed that the widespread distribution of $B$. glabrata, and its infection with $S$. mansoni, together with differences in the seasonal distribution of snails is correlated to high calcium levels that appear to promote large B. glabrata populations in wells and springs.

Other environmental conditions such as turbidity and water pollution have an influence on snail abundance. Becker et al. (153) found that turbidity and pesticide pollution, at concentrations similar to or higher than those considered safe in environmental risk assessment, are significant factors in increasing the incidence of B. pfeifferi and Bulinus africanus, the intermediate host for Schistosoma haematobium, the parasite responsible for urogenital schistosomiasis, and hence the likelihood of schistosomiasis transmission. Declines in snail competitors and predators, that are less tolerant to pesticides, increase the availability of food for intermediate snail hosts and decrease their mortality rate (154).

\section{INVASION PATTERNS}

\section{Long Distance (Global) Dispersal}

There are four cases of long-distance dispersal present in the literature; one case was reported for $B$. straminea (Caribbean islands, China), one for B. glabrata (Egypt), and two cases for B. tenagophila (Romania and Congo).
The dispersal of both B. glabrata and B. tenagophila (Congo) was implicated in local schistosomiasis transmission (Figure 2).

\section{Biomphalaria straminea}

B. straminea, one of the intermediate hosts for S. mansoni in South America, expanded its geographic range to colonize almost all the Caribbean islands (155). In Asia, B. straminea was first identified in Hong Kong water systems in the south of China in 1974 (50), in the subsequent years, the snails showed a dispersal capacity in different water courses in southern China. The snail species was found in numerous water bodies in Shenzhen city of Guangdong province, China in 1981 (156), and in the next 2 years showed a growing distribution in Shenzhen rivers, suggesting a spread from Hong Kong rivers systems (52).

Morphological and molecular study for seven populations of Biomphalaria snails collected in Guangdong indicated that five populations were closely related to B. kuhniana, another South American species refractory to schistosomes infection, the other two populations were identified as B. straminea and were more relative to B. straminea from Brazil (157). Controversially, further anatomical and molecular investigation of six Biomphalaria populations from Guangdong showed a close affinity between these populations and B. straminea from Brazil (158). Supporting the latter finding, a more recent study of $B$. straminea in Hong Kong identified two morphotypes of the species; black- and red-colored shell morphs of $B$. straminea in different districts in the new territories in Hong Kong, including places close to the mainland China border. Morphological and molecular analyses of the Hong Kong $B$. straminea showed that they are genetically indistinguishable and are similar to those obtained in mainland China and South America (159). The presence of B. straminea in Guangdong may be the result of multiple and different introduction routes and/or peripheral dispersal from Hong Kong populations via passive transport or container ship traffic or naturally due to connections between the water systems of the two adjacent localities (160).

The spread of B. straminea from Hong Kong to Guangdong confirms its ability to survive and form new colonies in mainland China and its capacity to spread along the rivers (161). B. straminea can adapt to drought periods and higher temperatures, an adaptability that will promote its spread to wider geographic areas in China in view of global warming and continued rise in the mean annual temperature of China (162). Further evidence is the recent invasion of the snail to Guanlan and Dasha rivers in Shenzhen city, Guangdong province, China (53). Moreover, recent maps for realized (Figure 3) and predicted spatial distributions of $B$. straminea in southern China, based on Geographical Information Systems (GIS) and species distribution modeling software (MaxEnt), showed the presence of B. straminea in many water habitats in Guangdong province and indicated possible suitable habitats in its surrounding provinces such as Guangxi and Fujian (163). 


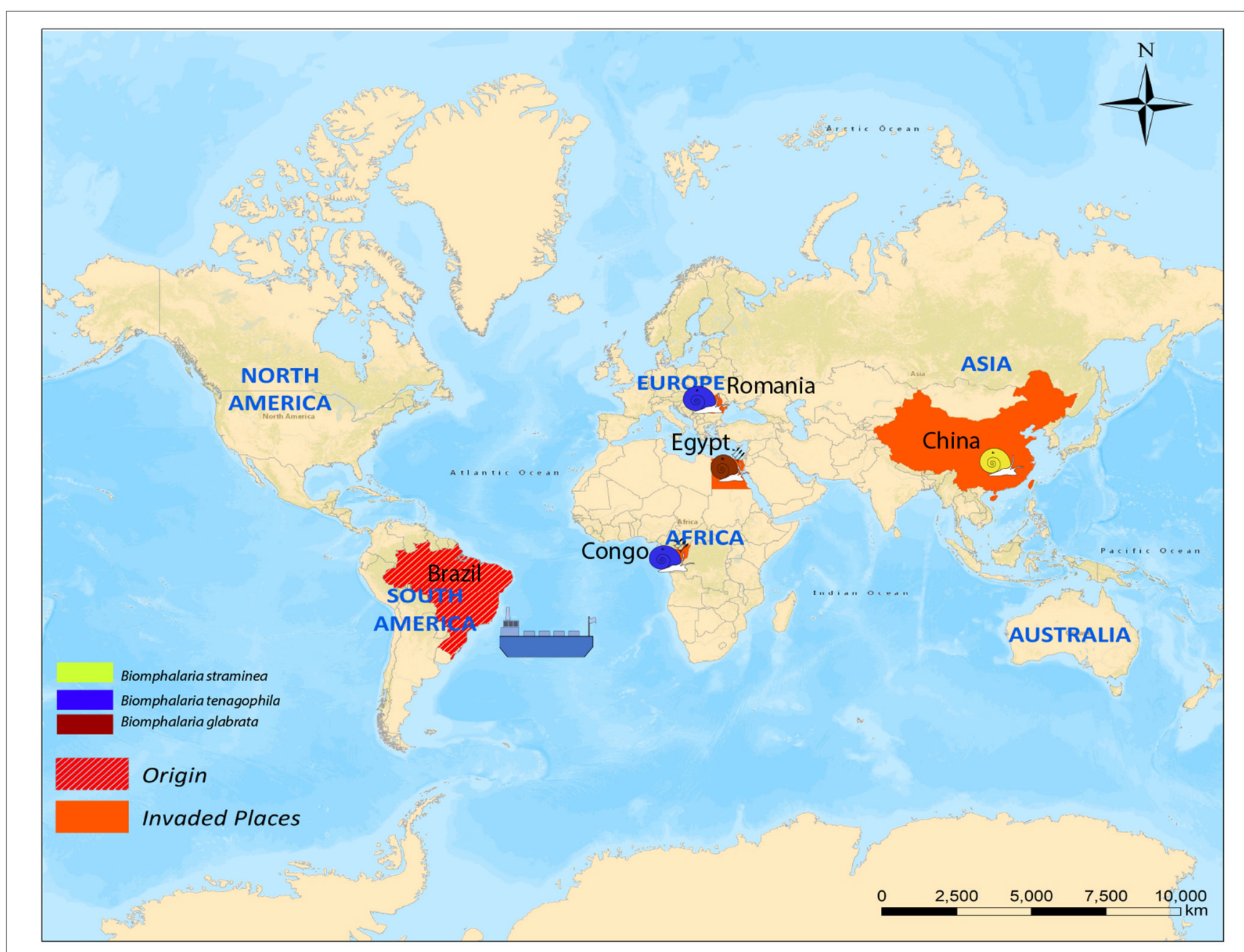

FIGURE 2 | Cases of long-distance dispersal of different Biomphalaria species.

\section{Biomphalaria glabrata}

B. glabrata was maintained in a laboratory setting in Egypt to conduct Schistosoma research from where it then allegedly escaped and was recorded from the field in the neighborhood of Cairo in 1981. Later on, in 1996 the snails were collected from water courses in Giza, Qalyoubiya and Kafr El-Sheikh governorates. Being an intermediate host of S. mansoni, its escape was considered a serious threat to public health in Egypt (44). In the following years, malacological surveys showed the invasion of the Nile Valley with hybrid snails resulted from mating of B. alexandrina and B. glabrata, distributed in El-Menia, El-Dakahliya, and Fayoum governorates. The hybrid snails were found naturally infected with S. mansoni (164). However, molecular investigations of Biomphalaria species collected from areas toward the north of Egypt, the Nile Delta and south of Egypt during 2002-2009 using species specific primers for B. alexandrina and B. glabrata did not identify B. glabrata in the collected populations $(165,166)$. Recent mapping of S. mansoni prevalence in the Nile Delta region showed high infection rates in schoolchildren (167) suggesting a recent contact with areas manifested with infected Biomphalaria. This merits further molecular analysis for Egyptian populations of Biomphalaria using mitochondrial and genomic sequences to identify species involved in S. mansoni transmission and to understand their role and biology of infection.

\section{Biomphalaria tenagophila}

The invasion of Neotropical snail B. tenagophila to Africa was reported from Kinshasa, Democratic Republic of Congo as confirmed by conchological, anatomical, and molecular studies. It was proposed that this species was introduced at the end of the 1960s (5). In Europe, B. tenagophila snails had been found in 2004 at Răbăgani, Romania, Eastern Europe but had been misidentified as the common European species, Planorbarius corneus (168). In the period between 2005 and 2007, the snail was collected from the same location and its identity was confirmed via morphological and molecular characterization that proved it as B. tenagophila. Molecular data obtained from 

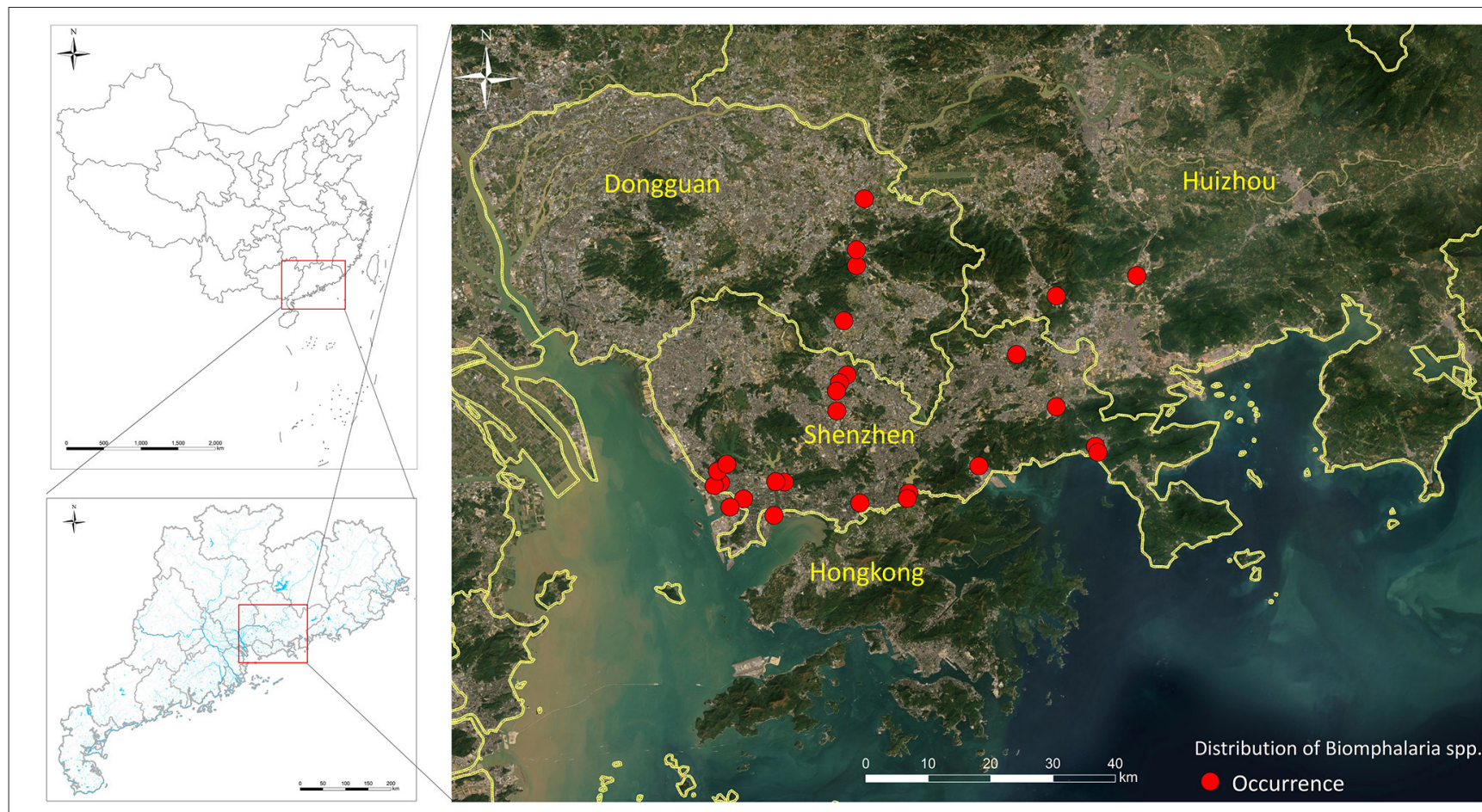

FIGURE 3 | Biomphalaria straminea distribution in the south part of China.

partial mitochondrial 16S ribosomal RNA gene amplification showed $99.74 \%$ similarity to $B$. tenagophila originated from Brazil. B. tenagophila is not only introduced, but also established in Răbăgani area in Romania. The snail's route of introduction is unknown but it is more likely to be introduced through migrating birds or by plants used in aquariums (66).

\section{Peripheral Dispersal}

Continued modifications of humans to aquatic environments through constructions of major reservoirs and hydroelectric dams and expanding irrigation schemes, quarries, drainage ditches, and aquaculture ponds, improve and create new freshwater bodies and potential snail habitats. Biomphalaria spp. rapidly colonize and establish dense populations in such habitats, which in turn facilitate schistosome transmission leading to disease outbreak (136, 169-171). Snails can be passively dispersed by floating aquatic plants or by human activities over the same lakes and rivers. For example, the invasive floating plant Salvinia was responsible for $B$. pfeifferi colonization in Lake Kariba in Zambia (172). Passive dispersal of Biomphalaria can also be delivered by water currents both during flooding, where water velocity is high so it sweeps away adhering snails, and also by slower drifting because of the habit of most pulmonates to detach and rise to the surface looking for food or as a deliberately dispersive behavior. In an experiment by Dazo et al. (143) they found that Biomphalaria and Bulinus were recovered as far as $4 \mathrm{~km}$ downstream after 1 day following release into a vegetationfree canal flowing rapidly at $0.42 \mathrm{~ms}^{-1}$. Field observations from some localities in Brazil indicate that seasonal distribution of
B. glabrata is characterized by generally lower snail densities in stagnant waters during the dry season however, higher densities in streams and canals during that time appear to be determined largely by the reduction of stagnancy through the addition of rainwater in the former and the flushing out of snails by seasonally increased water velocity in the latter (35). Many records of peripheral dispersal of different Biomphalaria spp. in many countries are found in the literature.

\section{CONSEQUENCES OF INVASIONS}

\section{Supporting Transmission of S. mansoni}

The problem with invasion of Biomphalaria susceptible to schistosomiasis is that one snail can undergo self-fertilization and act as a founder of an entire colony. Because an individual snail carries only part of the total genetic variation of its original population, the colonies established by the recent dispersal of that snail or even a small group of snails are expected to show reduced genetic diversity compared with their parental population (173). For example, B. alexandrina lost allelic diversity at several polymorphic loci after colonizing the Upper Nile in Egypt coming from the Nile Delta region (173). Increased genetic diversity of Biomphalaria tends to reduce the overall parasite transmission rate, supposedly due to a dilution effect where in the presence of high genetic diversity it is more likely that some snails are naturally resistant to Schistosoma infection, whereas reduced host genetic diversity could benefit $S$. mansoni through an overall increase in transmission rate (174). 
Following the introduction of $B$. tenagophila to Kinshasa, Congo in 1970, S. mansoni infected specimens were collected from the same area indicating the involvement of the snail in $S$. mansoni transmission and not a native African Biomphalaria (76, 175). This finding was confirmed based on a previous experience from Brazil where the first transmission site of $S$. mansoni through using $B$. tenagophila as intermediate host was discovered in the Paraiba valley, state of São Paulo. In the subsequent years, schistosomes showed a great adaptation to the new intermediate host and further spread throughout the valley (8).

B. pfeifferi has also been implicated in the increased prevalence of intestinal schistosomiasis in many countries following an extension of its distribution as exemplified by the rise of the disease in Malagasy high plateau, Madagascar after its colonization by B. pfeifferi $(176,177)$. In Egypt, B. glabrata was reported in long distances of water courses in Qalyoubiya, Giza, and Kafr El-Sheikh governorates $(44,46)$. Although no infected snails were collected, laboratory studies on the first generation obtained from field-collected specimens showed its susceptibility to a local strain of $S$. mansoni originally from Giza. The infection rate of B. glabrata snails was lower than that of $B$. alexandrina. Also, the incubation period was considerably shorter in B. alexandrina than B. glabrata which reflects the higher compatibility of the indigenous snails to local parasites. However, total number of cercariae produced per snail throughout the shedding period was higher in B. glabrata than in B. alexandrina. The results of experimental infection indicated that B. glabrata is as efficient as B. alexandrina in transmitting local S. mansoni parasites (46). The situation of B. glabrata became more complicated because the snail was able to hybridize with the local $B$. alexandrina snails producing a susceptible hybrid lineage. Some of the hybrid snails collected from ElGharbia, El-Behierah, El-Menia, Kafr El-Sheikh, Dakahlia, and Alexandria governorates were found naturally infected with $S$. mansoni (45). Field and laboratory studies suggested that $B$. glabrata and hybrid snails have a higher potential in transmitting S. mansoni, which could lead to an increase in schistosomiasis in associated communities (178).

The invasion of Upper Egypt with B. alexandrina following the construction of the High Dam has led to outbreaks of S. mansoni, with tremendous local increase in the prevalence levels in just a few years (179). Also, as a consequence of $B$. alexandrina introduction to newly reclaimed areas, epidemiological surveys on resident and settler populations showed $49.3 \%$ and $40 \%$ prevalence of S. mansoni in El-Manayef and El-Morra areas, respectively in Ismailia governorate. The seasonality of Biomphalaria infection in the new areas showed the presence of two peaks in August and November. These results confirmed the occurrence of transmission of S. mansoni which indicated that reclamation of parts of the desert using the Nile water had led to spread of schistosomiasis to these areas (45).

In Northeastern Brazil, a competitive displacement of $B$. glabrata by $B$. straminea occurred after the introduction of the latter species. This displacement was considered as a biological control measure since the introduced snails were thought to be resistant to $S$. mansoni infection and have a greater fecundity (180). However, field data from some endemic areas showed that human infection increased from 35.5 to $61.9 \%$ in the locality occupied by $B$. straminea, and decreased from 40.3 to $20.8 \%$ in that occupied by B. glabrata. These data suggest that $B$. straminea is involved in the transmission of schistosomiasis (181).

Transmission of schistosomiasis can't occur in the absence of a competent intermediate host snail, but once the obligate host has established, schistosomiasis transmission becomes a possibility (2). Although no schistosome larvae have been detected in $B$. straminea or $B$. tenagophila introduced to China and Europe (Romania), respectively, there is still a risk for intestinal schistosomiasis to be locally transmitted into these new geographic zones. The two species are susceptible intermediate host for $S$. mansoni and have been implicated in intestinal schistosomiasis transmission in their native habitats. Thus, global climate change and the possibility of the introduced snails to be in contact with schistosomes, could pose a public health risk. Human travel between countries for business, education or tourism made it possible to find schistosomiasis cases in non-endemic areas (182). For example, many reports of $S$. mansoni infected cases in immigrants or tourists visiting Romania and neighboring Hungary were reported (183). Also, more than 400 imported cases infected with African schistosomes (including S. mansoni and $S$. hematobium) were reported from numerous provinces in China between the years 1979 and 2011, owing to the sharp growth in China aided projects in Africa and labor services exported to Africa. It is estimated that over 1 million Chinese workers are now residing in Africa, increasing the risk of exposure to African schistosomiasis (160). Other possible ways of $S$. mansoni establishment include the introduction of infected snails in the same way by which uninfected ones were introduced and introduction of the parasite through Chinese or European laborers returning from endemic areas or visitors traveling for tourism or trade purposes. Once started it is possible that the life cycle could be maintained through other definitive hosts such as rodents.

\section{Supporting Transmission of Other Helminth Parasites}

In addition to its role as intermediate host for S. mansoni, Biomphalaria spp. may also act as intermediate hosts for other parasites of mammals, birds, and fish (Table 2). Moreover, different species of Biomphalaria were found naturally infected with cercariae and metacercariae of a wide range of trematodes of unknown life cycle $(73,217)$. Recently, both $B$. straminea and B. glabrata were shown to act as intermediate hosts of Austrodiplostomum compactum (Trematoda: Diplostomidae), the causative agent for ocular diplostomiasis in several species of fish in Brazil, a disease which may have potential impacts on native fish species and damage to fish farming. The two species were found infected with strigeid cercariae of the parasite (208). Biomphalaria can also act as intermediate hosts for different species of the nematode Angiostrongylus that infect domestic animals as well as humans. For example, Angiostrongylus 
TABLE 2 | Trematodes and nematodes parasites using Biomphalaria as intermediate host.

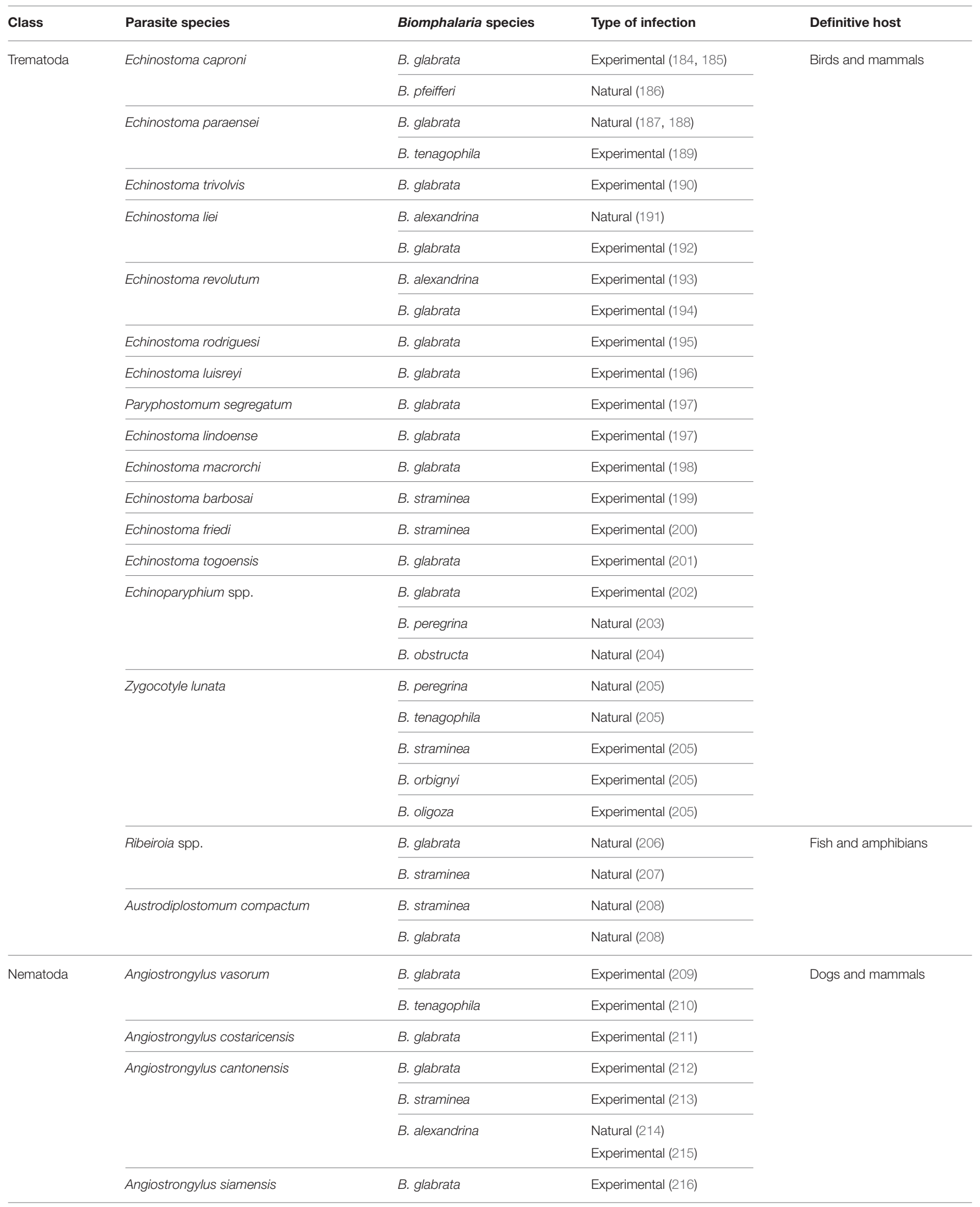


vasorum, that parasitizes the right ventricle of the heart and the pulmonary artery of dogs and wild carnivores in different parts of Europe, Canada, South America, and Africa (218, $219)$, is able to infect B. glabrata and B. tenagophila under laboratory conditions as evidenced by emergence of cercariae that could infect the vertebrate host $(209,210)$. The parasite can also cause diseases of the central nervous system in humans (220). B. glabrata and B. tenagophila act as intermediate hosts for the rat lung worms Angiostrongylus cantonensis and A. costaricensis the causative agents of eosinophilic meningitis and meningoencephalitis and abdominal angiostrongyliasis, respectively, in humans in many parts of the world (221). Within the snails, the parasite develops into the infective third-stage larvae and humans are infected after ingestion of infected snails (222). Infection with the rodent schistosome $S$. rodhaini were found in natural population of $B$. sudanica in some African countries such as Uganda and Burundi (15). Moreover, natural infections with 11 larvae of different trematode species were found in B. pfeifferi and B. sudanica from Tanzania (223).

\section{CONCLUSIONS}

The distribution of the snails will define the potential distribution of schistosomiasis and the likelihood of transmission. Many ecological factors regulate distribution and abundance of Biomphalaria spp. Hence, knowledge of the disease transmission is incomplete without available information on the ecology and biology of this intermediate host. There is a continuous need to document the changing and dynamic distribution of Biomphalaria due to continued environmental modifications and climatic changes.

Long distance dispersal of Biomphalaria is achieved through accidental and/ or deliberate introduction to new geographic areas. Dispersal of snail eggs and uninfected snails will not spread schistosomes, but dispersal of infected snails can spread the disease. Moreover, the new species may enhance disease transmission if it is more susceptible to local parasite than sympatric intermediate hosts. Thus, understanding the geographical origins of introduced snails, their modes of dispersal, and their rates of gene flow might assist efforts to understand the spread and establishment of schistosomiasis in the area of introduction. More studies are needed to identify the introduced species and understand their biology and the combination of morphological and molecular methodologies will be the best approach.

Snail distribution data can be used to develop prediction models for potential schistosomiasis risk areas and risk maps

\section{REFERENCES}

1. Poulin R, Paterson R, Townsend C, Tompkins D, Kelly D. Biological invasions and the dynamics of endemic diseases in freshwater ecosystems. Freshw Biol. (2011) 56:676-88. doi: 10.1111/j.1365-2427.2010. 02425.x for snail distribution and abundance using species modeling software. For this purpose, geographic coordinates should be collected for utilizing in GIS and remotely sensed data (224). The obtained risk maps can be used to apply the suitable public health strategies, and to guide other fieldwork. Also, the risk map will enable better resource distribution and adequate policies for snail control. The GIS approach is particularly recommended to provide estimates of the potential spread of invasive Biomphalaria species using data of occurrences through time that allow a functional estimation of the spread of the invader, which could then be related to rates of ecological changes and vector activity over time.

For better and effective control initiatives for schistosomiasis, periodic malacological surveys are recommended for the detection of Biomphalaria in new potential habitats and identification of species and infection status of collected snails. Swift actions should be taken to record any new occurrence of these snail intermediate hosts. Community education is another important intervention to aid control. Populations who are in contact with water for agricultural or other purposes should be able to morphologically identify schistosomiasis intermediate snail hosts and understand their role in disease transmission. A surveillance system could be established to monitor the distribution of snails. This system could be used to assist regional policies in controlling snails via application of molluscicides or other control approaches $(225,226)$.

\section{AUTHOR CONTRIBUTIONS}

$\mathrm{MRH}, \mathrm{DR}$, and X-NZ: conceived and designed the study, and wrote and edited the review. MRH, DR, and SL: data collection and interpretation. All authors read and approved the final manuscript.

\section{FUNDING}

This work was supported by the National Key Research and Development Program of China (No. 2016YFC1200500 and 2016YFC1202000).

\section{ACKNOWLEDGMENTS}

$\mathrm{MRH}$ was supported by a Post-doctoral Programme from the Ministry of Science and Technology of China and National Center for International Research on Tropical Diseases (Shanghai, China).
2. Conn DB. Aquatic invasive species and emerging infectious disease threats: a One Health perspective. Aquat Invas. (2014) 9:383-90. doi: 10.3391/ai.2014.9.3.12

3. Dhiman RC, Pahwa S, Dhillon G, Dash AP. Climate change and threat of vector-borne diseases in India: are we prepared? Parasitol Res. (2010) 106:763-73. doi: 10.1007/s00436-010-1767-4 
4. Pointier J-P, Augustin D. Biological control and invading freshwater snails. A case study. Comptes Rendus de l'Académie des Sciences-Series III-Sciences de la Vie. (1999) 322:1093-8. doi: 10.1016/S0764-4469(99)00108-0

5. Pointier J-P, David P, Jarne P. Biological invasions: the case of planorbid snails. J Helminthol. (2005) 79:249-56. doi: 10.1079/JOH2005292

6. DeJong RJ, Morgan JA, Paraense WL, Pointier J-P, Amarista M, AyehKumi PF, et al. Evolutionary relationships and biogeography of Biomphalaria (Gastropoda: Planorbidae) with implications regarding its role as host of the human bloodfluke, Schistosoma mansoni. Mol Biol Evol. (2001) 18:222539. doi: 10.1093/oxfordjournals.molbev.a003769

7. Campbell G, Jones CS, Lockyer AE, Hughes S, Brown D, Noble LR, et al. Molecular evidence supports an African affinity of the Neotropical freshwater gastropod, Biomphalaria glabrata, Say 1818, an intermediate host for Schistosoma mansoni. Proc R Soc Lond Ser B Biol Sci. (2000) 267:23518. doi: 10.1098/rspb.2000.1291

8. Paraense WL. The schistosome vectors in the Americas. Mem Inst Oswaldo Cruz. (2001) 96:7-16. doi: 10.1590/S0074-02762001000900002

9. Malek EA. Snail Hosts of Schistosomiasis and Other Snail-Transmitted Diseases in Tropical America: A Manual. Scientific Publication no. 478. Washington, DC: Pan Am Health Organ (1985).

10. Corrêa LR, Paraense WL. Susceptibility of Biomphalaria amazonica to infection with two strains of Schistosoma mansoni. Rev Inst Med Trop São Paulo. (1971) 13:387-90.

11. Richards CS. Infectivity of Schistosoma mansoni for Puerto Rican mollusks, including a new potential intermediate host. Am J Trop Med Hyg. (1963)12:26-33. doi: 10.4269/ajtmh.196 3.12 .26

12. Paraense WL, Corrêa L. Susceptibility of Biomphalaria peregrina from Brazil and Ecuador to two strains of Schistosoma mansoni. Rev Inst Med Trop São Paulo. (1973) 15:127-30.

13. Barbosa F. Survival in the field of Australorbis glabratus infected with Schistosoma mansoni. J Parasitol. (1963) 49:149. doi: 10.2307/3275695

14. Ohlweiler FP, Rossignoli TD, Palasio RG, Tuan R. Taxonomic diversity of Biomphalaria (Planorbidae) in São Paulo state, Brazil. Biota Neotrop. (2020) 20:e20200975. doi: 10.1590/1676-0611-bn-20200975

15. Brown D. Freshwater Snails of Africa and Their Medical Importance. London: Taylor and Francis (1994). doi: 10.1201/9781482295184

16. Lotfy WM, Hanelt B, Mkoji GM, Loker ES. Genotyping natural infections of Schistosoma mansoni in Biomphalaria alexandrina from Damietta, Egypt, with comparisons to natural snail infections from Kenya. J Parasitol. (2011) 97:156-9. doi: 10.1645/GE-2537.1

17. Taman A, El-Tantawy N, Besheer T, Taman S, Helal R. Schistosoma mansoni infection in a fishermen community, the Lake Manzala regionEgypt. Asian Pac J Trop Dis. (2014) 4:463-8. doi: 10.1016/S2222-1808(14) 60607-1

18. Duke B, Moore P. The use of a molluscicide, in conjunction with chemotherapy, to control Schistosoma haematobium at the Barombi Lake foci in Cameroon. I. The attack on the snail hosts, using N-tritylmorpholine, and the effect on transmission from snail to man. Tropenmed Parasitol. (1976) 27:297-313.

19. Rowel C, Fred B, Betson M, Sousa-Figueiredo JC, Kabatereine NB, Stothard JR. Environmental epidemiology of intestinal schistosomiasis in Uganda: population dynamics of Biomphalaria (Gastropoda: Planorbidae) in Lake Albert and Lake Victoria with observations on natural infections with digenetic trematodes. BioMed Res Int. (2015) 2015:717261. doi: 10.1155/2015/717261

20. Prentice M, Panesar T, Coles G. Transmission of Schistosoma mansoni in a large body of water. Ann Trop Med Parasit. (1970) 64:33948. doi: 10.1080/00034983.1970.11686703

21. Baalawy S. Some observations on the role of Lake Victoria in the transmission of Schistosoma mansoni. East Afr Med J. (1971) 48:383-8.

22. Kazibwe F, Makanga B, Rubaire-Akiiki C, Ouma J, Kariuki C, Kabatereine $\mathrm{N}$, et al. Ecology of Biomphalaria (Gastropoda: Planorbidae) in Lake Albert, Western Uganda: snail distributions, infection with schistosomes and temporal associations with environmental dynamics. Hydrobiologia. (2006) 568:433-44. doi: 10.1007/s10750-006-0224-y
23. Melman SD, Steinauer ML, Cunningham C, Kubatko LS, Mwangi IN, Wynn NB, et al. Reduced susceptibility to praziquantel among naturally occurring Kenyan isolates of Schistosoma mansoni. PLoS Negl Trop Dis. (2009) 3:e504. doi: 10.1371/journal.pntd.0000504

24. Mitiku H, Legesse M, Teklemariam Z, Erko B. Transmission of Schistosoma mansoni in Tikur Wuha area, Southern Ethiopia. Ethiop J Health Dev. (2010) 24:181-4. doi: 10.4314/ejhd.v24i3.68382

25. Gryseels B. The epidemiology of schistosomiasis in Burundi and its consequences for control. Trans R Soc Trop Med Hyg. (1991) 85:62633. doi: 10.1016/0035-9203(91)90371-5

26. Babiker A, Fenwick A, Daffalla A, Amin M. Focality and seasonality of Schistosoma mansoni transmission in the Gezira Irrigated Area, Sudan. J Trop Med Hyg. (1985) 88:57-63.

27. Mimpfoundi R, Greer G. Allozyme variation among populations of Biomphalaria pfeifferi (Krauss, 1848)(Gastropoda: Planorbidae) in Cameroon. J Moll Stud. (1990)56:461-7. doi: 10.1093/mollus/ 56.4.461

28. Coulibaly G, Madsen H. Seasonal density fluctuations of intermediate hosts of schistosomes in two streams in Bamako, Mali. J Afr Zool. (1990)104:20112.

29. Mouchet F, Labo R, Develoux M, Sellin B: Enquête sur les schistosomoses dans l'arrondissement de Gaya (République du Niger). Ann Soc Belg Méd Trop. (1987) 67:23-9.

30. Sturrock R, Diaw O-T, Talla I, Niang M, Piau J-P, Capron A. Seasonality in the transmission of schistosomiasis and in populations of its snail intermediate hosts in and around a sugar irrigation scheme at Richard Toll, Senegal. Parasitology. (2001) 123:77-89. doi: 10.1017/S0031182001 008125

31. Donnelly FA, Appleton C. Observations on the field transmission dynamics of Schistosoma mansoni and S. mattheei in southern Natal, South Africa. Parasitology. (1985) 91:281-90. doi: 10.1017/S00311820000 57371

32. Fenwick A, Cheesmond A, Amin M. The role of field irrigation canals in the transmission of Schistosoma mansoni in the Gezira Scheme, Sudan. Bull World Health Organ. (1981) 59:777.

33. Chandiwana S, Christensen N, Frandsen F. Seasonal patterns in the transmission of Schistosoma haematobium, S. mattheei and S. mansoni in the highveld region of Zimbabwe. Acta Trop. (1987) 44:433-44.

34. Ibikounlé M, Mouahid G, Sakiti N, Massougbodji A, Moné H. Freshwater snail diversity in Benin (West Africa) with a focus on human schistosomiasis. Acta Trop. (2009) 111:29-34. doi: 10.1016/j.actatropica.2009. 02.001

35. Kloos H, Passos LKJ, LoVerde P, Oliveira RC, Gazzinelli A. Distribution and Schistosoma mansoni infection of Biomphalaria glabrata in different habitats in a rural area in the Jequitinhonha Valley, Minas Gerais, Brazil: environmental and epidemiological aspects. Mem Inst Oswaldo Cruz. (2004) 99:673-81. doi: 10.1590/S0074-02762004000700002

36. Pointier J, Paraense WL, Mazille V. Introduction and spreading of Biomphalaria straminea (Dunker, 1848)(Mollusca: Pulmonata: Planorbidae) in Guadeloupe, French West Indies. Mem Inst Oswaldo Cruz. (1993) 88:44955. doi: 10.1590/S0074-02761993000300016

37. Pointier J, David P. Biological control of Biomphalaria glabrata, the intermediate host of schistosomes, by Marisa cornuarietis in ponds of Guadeloupe: long-term impact on the local snail fauna and aquatic flora. Biol Control. (2004) 29:81-9. doi: 10.1016/S1049-9644(03)00137-3

38. Barnish G, Christie JD, Prentice MA. Schistosoma mansoni control in Cul de Sac valley, Saint Lucia. I. A two-year focal surveillance-mollusciciding programme for the control of Biomphalaria glabrata. Trans $R$ Soc Trop Med Hyg. (1980) 74:488-92. doi: 10.1016/0035-9203(80)90064-4

39. Mavárez J, Steiner C, Pointier J, Jarne P. Evolutionary history and phylogeography of the schistosome-vector freshwater snail Biomphalaria glabrata based on nuclear and mitochondrial DNA sequences. Heredity. (2002) 89:266-72. doi: 10.1038/sj.hdy.6800128

40. Pointier J, Incani R, Balzan C, Chrosciechowski P, Prypchan S. Invasion of the rivers of the littoral central region of Venezuela by Thiara granifera and Melanoides tuberculata (Mollusca: Prosobranchia: Thiaridae) and the absence of Biomphalaria glabrata, snail host of Schistosoma mansoni. Nautilus. (1994) 107:124-8. 
41. Stryker GA, Koech DK, Loker ES. Growth of Biomphalaria glabrata populations in the presence of the ampullariid snails Pila ovata, Lanistes carinatus and Marisa cornuarietis. Acta Trop. (1991) 49:13747. doi: 10.1016/0001-706X(91)90061-N

42. Raccurt CP, Sodeman WA, Rodrick GL, Boyd WP. Biomphalaria glabrata in Haiti. Trans $R$ Soc Trop Med Hyg. (1985) 79:4557. doi: 10.1016/0035-9203(85)90063-X

43. Gomez Perez J, Vargas M, Malek EA. Displacement of Biomfhalaria glabrata by Thiara granifera under natural conditions in the Dominican Republic. Mem Inst Oswaldo Cruz. (1991) 86:341-7. doi: 10.1590/S0074-02761991000300008

44. Pflüger W. Introduction of Biomphalaria glabrata to Egypt and other African countries. Trans $R$ Soc Trop Med Hyg. (1982) 76:567. doi: 10.1016/0035-9203(82)90167-5

45. Yousif F, Ibrahim A, Abdel KA, El-Bardicy S. Invasion of the Nile Valley in Egypt by a hybrid of Biomphalaria glabrata and Biomphalaria alexandrina, snail vectors of Schistosoma mansoni. J Egypt Soc Parasitol. (1998) 28:569-82.

46. Yousif F, Haroun N, Ibrahim A, El-Bardicy S. Biomphalaria glabrata: a new threat for schistosomiasis transmission in Egypt. J Egypt Soc Parasitol. (1996) 26:191-205.

47. Caldeira RL, Vidigal TH, Simpson AJ, Carvalho OS. Genetic variability in Brazilian populations of Biomphalaria straminea complex detected by simple sequence repeat anchored polymerase chain reaction amplification. Mem Inst Oswaldo Cruz. (2001) 96:535-44. doi: 10.1590/S0074-02762001000400016

48. Barboza DM, Zhang C, Santos NC, Silva MMBL, Rollemberg CVV, de Amorim FJR, et al. Biomphalaria species distribution and its effect on human Schistosoma mansoni infection in an irrigated area used for rice cultivation in northeast Brazil. Geospat Health. (2012) 6:103-9. doi: 10.4081/gh.2012.128

49. Ferrari AD, Hofmann PR. First register of Biomphalaria straminea Dunker, 1848, ín Santa Catarina state. Rev Inst Med Trop São Paulo. (1992) 34:33-5. doi: 10.1590/S0036-46651992000100006

50. Meier-Brook C. A snail intermediate host of Schistosoma mansoni introduced into Hong Kong. Bull World Health Organ. (1974) 51:661.

51. Yipp MW. Distribution of the schistosome vector snail, Biomphalaria straminea (Pulmonata: Planorbidae) in Hong Kong. J Moll Stud. (1990) 56:47-55. doi: 10.1093/mollus/56.1.47

52. Pan S, Chen P, Rong S, Liu J, Wang J, Chen Z, et al. Investigation on Biomphalaria straminea, an intermediate host of Schistosoma mansoni in Shenzhen City. South Chin J Prev Med. (1993) 7:70-6.

53. Gao S, Li X, Huang S, Xie X, Mei S, Ruan C, et al. Primary investigation of distribution and ecological environment of Biomphalaria straminea in Dasha and Guanlan Rivers in Shenzhen areas. Chin Trop Med. (2013) 13:313-7.

54. Yang Y, Huang SY, Pei FQ, Chen Y, Jiang QW, Deng ZH, Zhou YB. Spatial distribution and habitat suitability of Biomphalaria straminea, intermediate host of Schistosoma mansoni, in Guangdong, China. Infect Dis Poverty. (2018) 7:109. doi: 10.1186/s40249-018-0492-6

55. Pointier J, Paraense WL, Corrêa LR. A potential vector of Schistosoma mansoni in Uruguay. Mem Inst Oswaldo Cruz. (1989) 84:281-8. doi: 10.1590/S0074-02761989000300001

56. Scarabino F. Lista sistemática de los Gastropoda dulciacuícolas vivientes de Uruguay. Comun Soc Malacol Uruguay. (2004) 8:347-56.

57. Amarista M, Niquil N, Balzan C, Pointier J-P. Interspecific competition between freshwater snails of medical importance: a Venezuelan example. Comptes Rend Acad Sci Ser III Sci. Vie. (2001) 324:143-8. doi: 10.1016/S0764-4469(00)01280-4

58. Paraense W, Zeledón-Araya R, Rojas-Herrera G. Biomphalaria straminea and other planorbid molluscs in Costa Rica. J Parasitol. (1981) 67:2823. doi: $10.2307 / 3280654$

59. Bianco K, Otero S, Oliver AB, Nahabedian D, Kristoff G. Resistance in cholinesterase activity after an acute and subchronic exposure to azinphosmethyl in the freshwater gastropod Biomphalaria straminea. Ecotoxicol Environ Saf. (2014) 109:85-92. doi: 10.1016/j.ecoenv.2014.07.038

60. Fernández MV, Hamann MI, Ostrowski-de Núñez M. Tremátodos larvales de Biomphalaria straminea (Mollusca: Planorbidae) en una arrocera en la provincia de Corrientes, Argentina. Rev Mex Biodiver. (2013) 84:75664. doi: $10.7550 / \mathrm{rmb} .33748$
61. Reeves WK, Dillon RT Jr, Dasch GA. Freshwater snails (Mollusca: Gastropoda) from the Commonwealth of Dominica with a discussion of their roles in the transmission of parasites. Am Malacol Bull. (2008) 24:5963. doi: 10.4003/0740-2783-24.1.59

62. Gomez JD, Malek EA, Vargas M. Species of Biomphalaria in the Dominican Republic and ecology of B. glabrata. J Med Appl Malacol. (1989) 1:173-81.

63. Malek EA. Studies on "tropicorbid" snails (Biomphalaria: Planorbidae) from the Caribbean and Gulf of Mexico areas, including the Southern United States. Malacologia. (1969) 7:183-209.

64. Cuba C, Corrêa L. Biomphalaria straminea no Peru e sua suscetibildade a cepas Brasileiras de Schistosoma mansoni. Rev Soc Bras Med Trop. (1977) 11:195-203. doi: 10.1590/S0037-86821977000600001

65. Sodeman Junior W, Rodrick G, Paraense WL, Gómez M. Biomphalaria straminea and other planorbids in the Dominican Republic. Mem Inst Oswaldo Cruz. (1985) 80 4:453-6. doi: 10.1590/S0074-02761985000400012

66. Majoros G, Fehér Z, Deli T, Földvári G. Establishment of Biomphalaria tenagophila snails in Europe. Emerg Infect Dis. (2008) 14:1812. doi: 10.3201/eid1411.080479

67. Couto LD, Tibirica SH, Pinheiro IO, Mitterofhe A, Lima AC, Castro MF, et al. Neglected tropical diseases: prevalence and risk factors for schistosomiasis and soil-transmitted helminthiasis in a region of Minas Gerais State, Brazil. Trans R Soc Trop Med Hyg. (2014)108:363-71. doi: 10.1093/trstmh/tru054

68. Cesar II, Martin SM, Rumi A, Tassara M. Mollusks (Gastropoda and Bivalvia) of the Multiple-Use Reserve Martin Garcia Island, Rio de la Plata River: biodiversity and ecology. Rev Bras Biol. (2012) 72:12130. doi: 10.1590/S1519-69842012000100014

69. Scholte RG, Carvalho OS, Malone JB, Utzinger J, Vounatsou P. Spatial distribution of Biomphalaria spp., the intermediate host snails of Schistosoma mansoni, in Brazil. Geospat Health. (2012) 6:S95-101. doi: 10.4081/gh.2012.127

70. Paraense WL. Biomphalaria tenagophila guaibensis ssp. n. from southern Brazil and Uruguay (Pulmonata: Planorbidae). I. Morphology. Mem Inst Oswaldo Cruz. (1984) 79:465-9. doi: 10.1590/S0074-02761984000400012

71. Borda CE, Rea MJ. Intermediate and definitive hosts of Schistosoma mansoni in Corrientes province, Argentina. Mem Inst Oswaldo Cruz. (2006) 101:2334. doi: 10.1590/S0074-02762006000900035

72. Borda CE, Rea MJ. Biomphalaria tenagophila potencial vector of Schistosoma mansoni in the Parana River basin (Argentina and Paraguay). Mem Inst Oswaldo Cruz. (2007) 102:191-5. doi: 10.1590/S0074-027620070050 00022

73. Fernández MV, Hamann MI, Kehr AI. Biology of Kalipharynx sp. (Trematoda: Digenea) metacercariae in Biomphalaria (Gasteropoda: Planorbidae) from northeastern Argentina. Rev Biol Trop. (2013) 61:1647-56. doi: 10.15517/rbt.v61i4.12807

74. Rumi A, Gregoric DE, Nunez V, Darrigran GA. [Latin American malacology. Freshwater mollusks from Argentina]. Rev Biol Trop. (2008) 56:77-111.

75. Paraense WL. Planorbidae, lymnaeidae and physidae of Peru (Mollusca: Basommatophora). Mem Inst Oswaldo Cruz. (2003) 98:767-71. doi: 10.1590/S0074-02762003000600010

76. Pointier JP, DeJong RJ, Tchuem Tchuente LA, Kristensen TK, Loker ES. A neotropical snail host of Schistosoma mansoni introduced into Africa and consequences for the schistosomiasis transmission Biomphalaria tenagophila in Kinshasa (Democratic Republic of Congo). Acta Trop. (2005) 93:1919. doi: 10.1016/j.actatropica.2004.11.003

77. Alebie G, Erko B, Aemero M, Petros B. Epidemiological study on Schistosoma mansoni infection in Sanja area, Amhara region, Ethiopia. Parasit Vector. (2014) 7:15. doi: 10.1186/1756-3305-7-15

78. Erko B, Medhin G, Berhe N, Abebe F, Gebre-Michael T, Gundersen SG. Epidemiological studies on intestinal schistosomiasis in Wondo Genet, southern Ethiopia. Ethiop Med J. (2002) 40:29-39.

79. Mekonnen Z, Haileselassie H, Medhin G, Erko B, Berhe N. Schistosomiasis mansoni focus in Mekele City, northern Ethiopia. Ethiop Med J. (2012) 50:331-6

80. Adenusi AA, Odaibo AB. Laboratory assessment of molluscicidal activity of crude aqueous and ethanolic extracts of Dalbergia sissoo plant parts against Biomphalaria pfeifferi. Travel Med Infect Dis. (2008) 6:21927. doi: 10.1016/j.tmaid.2007.12.004 
81. Adewunmi CO, Gebremedhin G, Becker W, Olurunmola FO, Dorfler G, Adewunmi TA. Schistosomiasis and intestinal parasites in rural villages in southwest Nigeria: an indication for expanded programme on drug distribution and integrated control programme in Nigeria. Trop Med Parasitol. (1993) 44:177-80.

82. Ahmed AA, Ibrahim NA, Idris MA. Laboratory Studies on the Prevalence and Cercarial Rhythms of Trematodes from Bulinus truncatus and Biomphalaria pfeifferi Snails from Khartoum State, Sudan. Sultan Qaboos Univ Med J. (2006) 6:65-9.

83. Amin MA, Fenwick A, Osgerby JM, Warley AP, Wright AN. A large-scale snail control trial with trifenmorph in the Gezira irrigation scheme, Sudan. Bull World Health Organ. (1976) 54:573-85.

84. Al-Sheikh AH, Dagal MA. The ecological differences between Bulinus beccari, the intermediate host of Schistsoma haematobium and Biomphalaria pfeifferi the intermediate host of S. mansoni in in Jazan Region, Saudi Arabia. J Egypt Soc Parasitol. (2011) 41:543-51.

85. Amankwa JA, Bloch P, Meyer-Lassen J, Olsen A, Christensen NO. Urinary and intestinal schistosomiasis in the Tono Irrigation Scheme, Kassena/Nankana District, upper east region, Ghana. Trop Med Parasitol. (1994) 45:319-23.

86. Bagalwa M, Baluku B. [Monthly variations in the level of infestation and the potential for transmission of Biomphalaria pfeifferi in 2 aquatic systems in Lwiro, Democratic Republic of Congo]. Med Trop. (1998) 58:372-4.

87. Baluku B, Bagalwa M, Basabose K. [Malacologic-schistosomal study of the refugee camps on the Plain of Ruzizi in the Democratic Republic of the Congo]. Med Trop. (1999) 59:39-42.

88. Campbell G, Noble LR, Rollinson D, Southgate VR, Webster JP, Jones CS. Low genetic diversity in a snail intermediate host (Biomphalaria pfeifferi Krass, 1848) and schistosomiasis transmission in the Senegal River Basin. Mol Ecol. (2010) 19:241-56. doi: 10.1111/j.1365-294X.2009.04463.x

89. Tchuente LA, Southgate VR, Theron A, Jourdane J, Ly A, Gryseels B. Compatibility of Schistosoma mansoni and Biomphalaria pfeifferi in northern Senegal. Parasitology. (1999) 118:595-603. doi: 10.1017/S00311820990 04345

90. Mutuku MW, Dweni CK, Mwangi M, Kinuthia JM, Mwangi IN, Maina GM, et al. Field-derived Schistosoma mansoni and Biomphalaria pfeifferi in Kenya: a compatible association characterized by lack of strong local adaptation, and presence of some snails able to persistently produce cercariae for over a year. Parasit Vector. (2014) 7:533. doi: 10.1186/s13071-014-0533-3

91. Opisa S, Odiere MR, Jura WG, Karanja DM, Mwinzi PN. Malacological survey and geographical distribution of vector snails for schistosomiasis within informal settlements of Kisumu City, western Kenya. Parasit Vector. (2011) 4:226. doi: 10.1186/1756-3305-4-226

92. Chimbari MJ, Dhlomo E, Mwadiwa E, Mubila L. Transmission of schistosomiasis in Kariba, Zimbabwe, and a cross-sectional comparison of schistosomiasis prevalences and intensities in the town with those in Siavonga in Zambia. Ann Trop Med Parasitol. (2003) 97:60516. doi: 10.1179/000349803225001508

93. Labbo R, Garba A, Louboutin-Croc JP, Ernould JC, Sellin B, Chippaux JP, et al. The spread of Biomphalaria pfeifferi in the Niger River valley, Niger. Ann Trop Med Parasitol. (2003) 97:209-12. doi: 10.1179/000349803235001507

94. Dabo A, Sow MY, Sangare L, Maiga I, Keita A, Bagayoko Y, et al. [Transmission of schistosomiasis in an urban population and prevalence of intestinal helminthiasis in Bamako, Mali]. Bull Soc Pathol Exot. (2003) 96:187-90.

95. De Clercq D, Rollinson D, Diarra A, Sacko M, Coulibaly G, Landoure A, et al. Schistosomiasis in Dogon country, Mali: identification and prevalence of the species responsible for infection in the local community. Trans R Soc Trop Med Hyg. (1994) 88:653-6. doi: 10.1016/0035-9203(94) 90212-7

96. Dennis E, Vorkpor P, Holzer B, Hanson A, Saladin B, Saladin K, et al. Studies on the epidemiology of schistosomiasis in Liberia: the prevalence and intensity of schistosomal infections in Bong County and the bionomics of the snail intermediate hosts. Acta Trop. (1983) 40:205-29.

97. Saladin B, Saladin K, Holzer B, Dennis E, Hanson A, Degremont A. A pilot control trial of schistosomiasis in central Liberia by mass chemotherapy of target populations, combined with focal application of molluscicide. Acta Trop. (1983) 40:271-95.

98. Diakite NR, Adja AM, von Stamm T, Utzinger J, N'Goran EK. [Epidemiological baseline situation before the construction of a small dam in five villages of Bouake, central Cote-d'Ivoire]. Bull Soc Pathol Exot. (2010) 103:22-8. doi: 10.1007/s13149-009-0029-4

99. Dida GO, Gelder FB, Anyona DN, Matano AS, Abuom PO, Adoka SO, et al. Distribution and abundance of schistosomiasis and fascioliasis host snails along the Mara River in Kenya and Tanzania. Infect Ecol Epidemiol. (2014) 4:24281. doi: 10.3402/iee.v4.24281

100. Ibikounle M, Gbedjissi LG, Ogouyemi-Hounto A, Batcho W, Kinde-Gazard D, Massougbodji A. [Schistosomiasis and soiltransmitted helminthiasis among schoolchildren of Nikki and Perere, two northeastern towns of Benin]. Bull Soc Pathol Exot. (2014) 107:171-6. doi: 10.1007/s13149-014-0344-y

101. Moyou-Somo R, Kouemeni LE, Ndjamen B, Ngogang J, Dongla R, LongangTchatchouang V, et al. A new focus of Schistosoma mansoni in Yoro village, Mbam and Inoubou Division, Cameroon. Am J Trop Med Hyg. (2003) 69:74-7. doi: 10.4269/ajtmh.2003.69.74

102. Njiokou F, Yimta Tsemo LC, Kuete T, Same Ekobo A. [Dynamics of intestinal schistosomiasis in Cameroon: evolution of transmission in the mixed zone of Nkolmebanga, Lekie]. Med Trop. (2004) 64:351-4.

103. Hazza YA, Arfaa F, Haggar M. Studies on schistosomiasis in Taiz Province, Yemen Arab Republic. Am J Trop Med Hyg. (1983) 32:10238. doi: 10.4269/ajtmh.1983.32.1023

104. Hira PR. Seasonal population densities of snails transmitting urinary and intestinal schistosomiasis in Lusaka, Zambia. Trop Geogr Med. (1975) 27:8392.

105. Mungomba LM, Chandiwana SK, Madesen H. Schistosomiasis around Siavonga, on the shores of Lake Kariba, Zambia. Ann Trop Med Parasitol. (1993) 87:365-71. doi: 10.1080/00034983.1993.118 12780

106. Moser W, Greter H, Schindler C, Allan F, Ngandolo BN, Moto DD, et al. The spatial and seasonal distribution of Bulinus truncatus, Bulinus forskalii and Biomphalaria pfeifferi, the intermediate host snails of schistosomiasis, in N'Djamena, Chad. Geospat Health. (2014) 9:109-18. doi: 10.4081/gh. 2014.9

107. Odongo-Aginya EI, Kironde FK, Kabatereine NB, Kategere P, Kazibwe F. Effect of seasonal rainfall and other environmental changes, on snail density and infection rates with Schistosoma mansoni fifteen years after the last snails' study in Kigungu, Entebbe, Uganda. East Afr Med J. (2008) 85:55663. doi: 10.4314/eamj.v85i11.9675

108. Poda JN, Wango SP, Sorgho H, Dianou D. [Recent evolution of schistosomiasis in the water project of Sourou in Burkina Faso]. Bull Soc Pathol Exot. (2004) 97:15-8.

109. Yousif F, El-Emam M, Abdel-Kader A, El-Din AS, El-Hommossany K, Shiff C. Schistosomiasis in newly reclaimed areas in Egypt. 1-distribution and population seasonal fluctuation of intermediate host snails. J Egypt Soc Parasitol. (1998) 28:915-28.

110. Abou-El-Naga IF. Biomphalaria alexandrina in Egypt: past, present and future. J Biosci. (2013) 38:665-72. doi: 10.1007/s12038-013-9329-4

111. Lotfy WM, DeJong RJ, Black BS, Loker ES. Specific identification of Egyptian Biomphalaria species and possible hybrids using the polymerase chain reaction based on nuclear and mitochondrial loci. Mol Cell Probes. (2005) 19:21-5. doi: 10.1016/j.mcp.2004.08.003

112. Doumenge J-P, Mott KE, Cheung C. Atlas of the Global Distribution of Schistosomiasis Continued. Presses universitaires de Bordeaux (1987).

113. Cridland C. Susceptibility of the snail Biomphalaria alexandrina from the UAR and the Sudan to infection with a strain of Schistosoma mansoni from Tanzania. Bull World Health Organ. (1970) 43:809.

114. Standley CJ, Wade CM, Stothard JR. A fresh insight into transmission of schistosomiasis: a misleading tale of Biomphalaria in Lake Victoria. PLoS ONE. (2011) 6:e26563. doi: 10.1371/journal.pone.0026563

115. Morgan JA, DeJong RJ, Lwambo NJ, Mungai BN, Mkoji GM, Loker ES. First report of a natural hybrid between Schistosoma mansoni and S. rodhaini. J Parasitol. (2003) 89:416-8. doi: 10.1645/0022-3395(2003)0890416:FROANH2.0.CO;2 
116. Stensgaard A, Jorgensen A, Kabatereine NB, Malone JB, Kristensen TK. Modeling the distribution of Schistosoma mansoni and host snails in Uganda using satellite sensor data and Geographical Information Systems. Parassitologia. (2005) 47:115-25.

117. Onori E. Preliminary Note on the Presence of Biomphalaria Sudanica (Martens) in Ghana and its susceptibility to a local strain of S. mansoni. West Afr Med J. (1965) 14:3-5.

118. Birrie H, Erko B, Tedla S. Intestinal helminthic infections in the southern Rift Valley of Ethiopia with special reference to schistosomiasis. East Afr Med J. (1994) 71:447-52.

119. Standley CJ, Goodacre SL, Wade CM, Stothard JR. The population genetic structure of Biomphalaria choanomphala in Lake Victoria, East Africa: implications for schistosomiasis transmission. Parasit Vector. (2014) 7:524. doi: 10.1186/s13071-014-0524-4

120. Adriko M, Standley CJ, Tinkitina B, Mwesigwa G, Kristensen TK, Stothard JR, et al. Compatibility of Ugandan Schistosoma mansoni isolates with Biomphalaria snail species from Lake Albert and Lake Victoria. Acta Trop. (2013) 128:303-8. doi: 10.1016/j.actatropica.2013.02.014

121. Greer GJ, Mimpfoundi R, Malek EA, Joky A, Ngonseu E, Ratard RC. Human schistosomiasis in Cameroon. II. Distribution of the snail hosts. Am J Trop Med Hyg. (1990) 42:573-80. doi: 10.4269/ajtmh.1990.42.573

122. McCullough FS. Observations on Bilharziasis and the Potential Snail Hosts in the Republic of the Congo (Brazzaville). Bull World Health Organ. (1964) 30:375-88

123. Frandsen F, Bennike T, Cridland C. Studies on Schistosoma intercalatum Fisher, 1934 and its intermediate snail host in the Kisangani area, Zaire. Ann Soc Belg Méd Trop. (1978) 58:21-31.

124. Caldeira RL, Vidigal TH, Matinella L, Simpson AJ, Carvalho OS. Identification of planorbids from Venezuela by polymerase chain reaction amplification and restriction fragment length polymorphism of internal transcriber spacer of the RNA ribosomal gene. Mem Inst Oswaldo Cruz. (2000) 95:171-7. doi: 10.1590/S0074-02762000000200007

125. Gryseels B, Nkulikyinka L, Kabahizi E, Maregeya E. A new focus of Schistosoma mansoni in the highlands of Burundi. Ann Soc Belg Méd Trop. (1978) 67:247-57.

126. Brown D. A survey of the Mollusca of Lake Chad, Central Africa. Appendix A. Report on a collection of Planorbidae and Ancylidae. Rev Zool Afr. (1974) 88:331-43.

127. Pimentel D. Life history of Australorbis glabratus, the intermediate snail host of Schistosoma mansoni in Puerto Rico. Ecology. (1957) 38:57680. doi: $10.2307 / 1943122$

128. Ritchie LS, Berrios-Duran LA, Deweese R. Biological potentials of Australorbis glabratus: growth and maturation. Am J Trop Med Hyg. (1963) 12:264-8. doi: 10.4269/ajtmh.1963.12.264

129. Barbosa FS, Barbosa CS. The bioecology of snail vectors for schitosomiasis in Brazil. Cad Saúde Públ. (1994) 10:2009. doi: 10.1590/S0102-311X1994000200007

130. Pessoa SB, Martins AV. Parasitologia Médica. 11a ed. Rio de Janeiro: Guanabara Koogan, (1982).

131. Kloos H, Souza Cd, Gazzinelli A, Soares Filho BS, Temba PdC, Bethony J, et al. The distribution of Biomphalaria spp. in different habitats in relation to physical, biological, water contact and cognitive factors in a rural area in Minas Gerais, Brazil. Mem Inst Oswaldo Cruz. (2001) 96:5766. doi: 10.1590/S0074-02762001000900008

132. Malek EA. Factors conditioning the habitat of bilharziasis intermediate hosts of the family Planorbidae. Bull World Health Organ. (1958) 18:785.

133. Rollinson D. Biomphalaria: Natural history, ecology and schistosome transmission. In: Toledo R, Fried B, editors. Biomphalaria Snails and Larval Trematodes. New York, NY: Springer (2011). p. 57-79. doi: 10.1007/978-1-4419-7028-2_3

134. Chimbari M, Madsen H, Ndamba J. The potential of using fish to control intermediate host snails for schistosomiasis in Zimbabwe. Parasitol Int. (1998) 47:278. doi: 10.1016/S1383-5769(98)80784-8

135. Sokolow SH, Huttinger E, Jouanard N, Hsieh MH, Lafferty KD, Kuris AM, et al. Reduced transmission of human schistosomiasis after restoration of a native river prawn that preys on the snail intermediate host. Proc Natl Acad Sci USA. (2015) 112:9650-5. doi: 10.1073/pnas.1502651112
136. Sokolow SH, Jones IJ, Jocque M, La D, Cords O, Knight A, et al. Nearly 400 million people are at higher risk of schistosomiasis because dams block the migration of snail-eating river prawns. Philos Trans R Soc Lond B Biol Sci. (2017) 372:20160127. doi: 10.1098/rstb.2016.0127

137. Pointier JP, Jourdane J. Biological control of the snail hosts of schistosomiasis in areas of low transmission: the example of the Caribbean area. Acta Trop. (2000) 77:53-60. doi: 10.1016/S0001-706X(00)00123-6

138. Frandsen F, Madsen H. A review of Helisoma duryi in biological control. Acta Trop. (1979) 36:67-84

139. Yousif F, El-Emam M, Abdel KA, El-Din AS, El-Hommossany K, Shiff C. Schistosomiasis in newly reclaimed areas in Egypt. 2-Patterns of transmission. J Egypt Soc Parasitol. (1999) 29:635-48.

140. Kalinda C, Chimbari M, Mukaratirwa S. Implications of changing temperatures on the growth, fecundity and survival of intermediate host snails of schistosomiasis: a systematic review. Int J Environ Res Public Health. (2017) 14:80. doi: 10.3390/ijerph14010080

141. Stensgaard AS, Vounatsou P, Sengupta ME, Utzinger J. Schistosomes, snails and climate change: current trends and future expectations. Acta Trop. (2019) 190:257-68. doi: 10.1016/j.actatropica.2018.09.013

142. De Leo GA, Stensgaard AS, Sokolow SH, N'Goran EK, Chamberlin AJ, Yang GJ, Utzinger J. Schistosomiasis and climate change. BMJ. (2020):371:m4324. doi: 10.1136/bmj.m4324

143. Dazo B, Hairston NG, Dawood I. The ecology of Bulinus truncatus and Biomphalaria alexandrina and its implications for the control of bilharziasis in the Egypt-49 project area. Bull World Health Organ. (1966) 35:339.

144. Yousif F, Kamel G, El Emam M, Mohamed S. Ecology of Biomphalaria alexandrina the snail vector of Schistosoma mansoni in Egypt. J Egypt Soc Parasitol. (1993) 23:29-42.

145. El-Emam M, Madsen H. The effect of temperature, darkness, starvation and various food types on growth, survival and reproduction of Helisoma duryi, Biomphalaria alexandrina and Bulinus truncatus (Gastropoda: Planorbidae). Hydrobiologia. (1982) 88:265-75. doi: 10.1007/BF00 008506

146. Sturrock R. Field studies on the population dynamics of Biomphalaria glabrata, intermediate host of Schistosoma mansoni on the West Indian island of St. Lucia. Int J Parasitol. (1973) 3:165-74. doi: 10.1016/0020-7519(73)90022-2

147. Appleton C. The influence of temperature on the life-cycle and distribution of Biomphalaria pfeifferi (Krauss, 1948) in South-Eastern Africa. Int J Parasitol. (1977) 7:335-45. doi: 10.1016/0020-7519(77) 90057-1

148. Stensgaard AS, Jørgensen A, Kabatereine NB, Rahbek C, Kristensen TK. Modeling freshwater snail habitat suitability and areas of potential snailborne disease transmission in Uganda. Geospat Health. (2006) 1:93104. doi: 10.4081/gh.2006.284

149. Lodge D, Brown K, Klosiewski S, Stein R, Covich A, Leathers B, et al. Distribution of freshwater snails: spatial scale and the relative importance of physicochemical and biotic factors. Am Malacol Bull. (1987) 5:73-84.

150. Alves W. Chemical constituents of surface water in Southern Rhodesia, with special reference to the molluscan vectors of bilharziasis. Bull World Health Organ. (1958) 18:1071.

151. Harrison A, Nduku W, Hooper A. The effects of a high magnesiumto-calcium ratio on the egg-laying rate of an aquatic planorbid snail, Biomphalaria pfeifferi. Ann Trop Med Parasitol. (1966) 60:212. doi: 10.1080/00034983.1966.11686407

152. El-Khayat H, Ismail N, Mahmoud K, Ragb F, El-Said K, Mostafa B, et al. Evaluation of some chemical parameters as potential determinants of freshwater snails with special reference to medically important snails in Egypt. World Acad Sci Eng Technol. (2011) 59:1313-26. doi: 10.5281/zenodo.1074936

153. Becker JM, Ganatra AA, Kandie F, Mühlbauer L, Ahlheim J, Brack W, et al. pesticide pollution in freshwater paves the way for schistosomiasis transmission. Sci Rep. (2020) 10:3650. doi: 10.1038/s41598-020-62951-7

154. Halstead NT, Hoover CM, Arakala A, Civitello DJ, De Leo GA, Gambhir $\mathrm{M}$, et al. Agrochemicals increase risk of human schistosomiasis by supporting higher densities of intermediate hosts. Nat Commun. (2018) 9:837. doi: 10.1038/s41467-018-03189-w 
155. Ferguson F, Buckmire K. Notes on the freshwater molluscs of Grenada. $\mathrm{Br}$ West Indies Carib J Sci. (1974) 14:147-8.

156. Liu Y, Huang Y, Zhuang W. The discovery of Biomphalaria straminea (Dunker), an intermediate host of Schistosoma mansoni, from China. Acta Zoo Sin. (1982) 7:256.

157. Attwood SW, Huo GN, Qiu JW. Update on the distribution and phylogenetics of Biomphalaria (Gastropoda: Planorbidae) populations in Guangdong Province, China. Acta Trop. (2015) 141:258-70. doi: 10.1016/j.actatropica.2014.04.032

158. Habib MR, Lv S, Guo YH, Gu WB, Standley J, Caldiera RL, et al. Morphological and molecular characterization of invasive Biomphalaria snails in Southern China. Infect Dis Povert. (2018) 7:120. doi: 10.1186/s40249-018-0505-5

159. Zeng X, Yiu WC, Cheung KH, Yip HY, Nong W, He P, et al. Distribution and current infection status of Biomphalaria straminea in Hong Kong. Parasit Vector. (2017) 10:351. doi: 10.1186/s13071-017-2285-3

160. Wang W, Liang Y-S, Hong Q-B, Dai J-R. African schistosomiasis in mainland China: risk of transmission and countermeasures to tackle the risk. Parasit Vector. (2013) 6:249. doi: 10.1186/1756-3305-6-249

161. IPCC. Climate Change 2001: the scientific basis. In: Houghton JT, Ding Y, Griggs DJ, Noguer M, van der Linden PJ, Dai X, Maskell K, and Johnson CA, editors. Contribution of Working Group I to the Third Assessment Report of the Intergovernmental Panel on Climate Change. Cambridge, UK; New York, NY: Cambridge University Press (2001). p. 881.

162. Zhou X-N, Yang G-J, Yang K, Wang X-H, Hong Q-B, Sun L-P, et al. Potential impact of climate change on schistosomiasis transmission in China. Am J Trop Med Hyg. (2008) 78:188-94. doi: 10.4269/ajtmh.2008. 78.188

163. Habib MR, Guo Y-H, Lv S, Gu W-B, Li X-H, Zhou X-N. Predicting the spatial distribution of Biomphalaria straminea, a potential intermediate host for Schistosoma mansoni, in China. Geospat Health. (2016) 11:453. doi: 10.4081/gh.2016.453

164. Kristensen TK, Yousif F, Raahauge P. Molecular characterisation of Biomphalaria spp in Egypt. J Moll Stud. (1999) 65:1336. doi: 10.1093/mollus/65.1.133

165. Lotfy WM, Dejong RJ, Abdel-Kader A, Loker ES. A molecular survey of Biomphalaria in Egypt: is B. glabrata present? Am J Trop Med Hyg. (2005) 73:131-9. doi: 10.4269/ajtmh.2005.73.131

166. Mohamed AH, El-Din ATS, Mohamed AM, Habib MR. The relationship between genetic variability and the susceptibility of Biomphalaria alexandrina snails to Schistosoma mansoni infection. Mem Inst Oswaldo Cruz. (2012) 107:326-37. doi: 10.1590/S0074-02762012000300006

167. Haggag AA, Rabiee A, Abd Elaziz KM, Gabrielli AF, Abdel Hay R, Ramzy RMR. Mapping of Schistosoma mansoni in the Nile Delta, Egypt: assessment of the prevalence by the circulating cathodic antigen urine assay. Acta Trop. (2017) 167:9-17. doi: 10.1016/j.actatropica.2016. 11.038

168. Gagiu A. On the extinction of the relict snail Theodoxus prevostianus Pfeiffer 1828 in Răbăgani. Romania. Nymphaea. (2004) 31:75-81.

169. Jordan P, Christie J, Unrau G. Schistosomiasis transmission with particular reference to possible ecological and biological methods of control. A review. Acta Trop. (1980) 37:95-135.

170. Southgate V. Schistosomiasis in the Senegal River Basin: before and after the construction of the dams at Diama, Senegal and Manantali, Mali and future prospects. J Helminthol. (1997) 71:125-32. doi: 10.1017/S0022149X00015790

171. Steinmann P, Keiser J, Bos R, Tanner M, Utzinger J. Schistosomiasis and water resources development: systematic review, meta-analysis, and estimates of people at risk. Lancet Infect Dis. (2006) 6:41125. doi: 10.1016/S1473-3099(06)70521-7

172. Hira PR. Transmission of Schistosomiasis in Lake Kariba, Zambia. Nature. (1969) 224:670-2. doi: 10.1038/224670a0

173. Vrijenhoek R, Graven M. Population genetics of Egyptian Biomphalaria alexandrina (Gastropoda, Planorbidae). J Heredity. (1992) 83:255-61. doi: 10.1093/oxfordjournals.jhered.a111210

174. Sandland GJ, Foster AV, Zavodna M, Minchella DJ. Interplay between host genetic variation and parasite transmission in the Biomphalaria glabrata-Schistosoma mansoni system. Parasitol Res. (2007) 101:10839. doi: 10.1007/s00436-007-0593-9
175. Colaert J, Lokombe B, Fain A, Vandepitte J, Wery M. Présence d'un petit foyer autochtone de Bilharziose à $S$. mansoni à Kinshasa (République du Zaïre). Ann Soc belge Méd Trop. (1977) 57:157-62.

176. Pflüger W. Ecological studies in Madagascar of Biomphalaria pfeifferi, intermediate host of Schistosoma mansoni. 2. Biology and dynamics in the non-endemic area of Antananarivo. Arch Inst Pasteur Madagascar. (1978) 46:241-69.

177. Spencer SA, Penney JM, Russell HJ, Howe AP, Linder C, Rakotomampianina $\mathrm{AL}$, et al. High burden of Schistosoma mansoni infection in school-aged children in Marolambo District, Madagascar. Parasit Vectors. (2017) 10:18. doi: 10.1186/s13071-017-2249-7

178. Yousif F, Ibrahim A, El Bardicy S. Compatibility of Biomphalaria alexandrina, Biomphalaria glabrata and a hybrid of both to seven strains of Schistosoma mansoni from Egypt. J Egypt Soc Parasitol. (1998) 28:863-81.

179. Barakat RM. Epidemiology of schistosomiasis in Egypt: travel through time: review. J Adv Res. (2013) 4:425-32. doi: 10.1016/j.jare.2012.07.003

180. Michelson E, Dubois L. Competitive interaction between two snail hosts of Schistosoma mansoni: laboratory studies on Biomphalaria glabrata and B. straminea. Rev Inst Med Trop São Paulo. (1979) 21:246.

181. Favre TC, Pieri OS, Zani LC, Ferreira JM, Domás GG, Beck LH, et al. Longitudinal study on the natural infection of Biomphalaria straminea and B. glabrata by Schistosoma mansoni in an endemic area of schistosomiasis in Pernambuco, Brazil. Mem Inst Oswaldo Cruz. (2002) 97:465-75. doi: 10.1590/S0074-02762002000400003

182. Aytaç B, Sehitoglu I. A rare parasitic infection in Turkey: schistosomiasis. Case report. Turk J Pathol. (2012) 28:175-7. doi: 10.5146/tjpath.2012. 01120

183. Neghina R, Neghina AM, Marincu I, Iacobiciu I. Epidemiology and history of human parasitic diseases in Romania. Parasitol Res. (2011) 108:133346. doi: 10.1007/s00436-011-2256-0

184. Ataev GL, Coustau C. Cellular response to Echinostoma caproni infection in Biomphalaria glabrata strains selected for susceptibility/resistance. Dev Comp Immunol. (1999) 23:187-98. doi: 10.1016/S0145-305X(99)00023-3

185. Bouchut A, Sautiere P, Coustau C, Mitta G. Compatibility in the Biomphalaria glabrata/Echinostoma caproni model: potential involvement of proteins from hemocytes revealed by a proteomic approach. Acta Trop. (2006) 98:234-46. doi: 10.1016/j.actatropica.2006.05.007

186. Richard J, Brygoo E. [Life cycle of the trematode Echinostoma caproni Richard, 1964 (Echinostomatoidea)(author's transl)]. Ann Parasitol Hum Comp. (1977) 53:265-75. doi: 10.1051/parasite/1978533265

187. Lie KJ, Basch PF. The life history of Echinostoma paraensei sp. n.(Trematoda: Echinostomatidae). J Parasitol. (1967):1192-9. doi: 10.2307/3276679

188. Maldonado A, Vieira G, Garcia J, Rey L, Lanfredi R. Biological aspects of a new isolate of Echinostoma paraensei (Trematoda: Echinostomatidae): susceptibility of sympatric snails and the natural vertebrate host. Parasitol Res. (2001) 87:853-9. doi: 10.1007/s004360100450

189. Garcia JS, Maldonado Junior A, Bidau CJ, Corrêa LdR, Lanfredi RM, Coelho PMZ. The effect of early infection with Echinostoma paraensei on the interaction of Schistosoma mansoni with Biomphalaria glabrata and Biomphalaria tenagophila. Mem Inst Oswaldo Cruz. (2010) 105:499503. doi: 10.1590/S0074-02762010000400026

190. Frazer BA, Fried B. Single-species infections of Echinostoma caproni cercariae in pulmonate snails and concurrent infections of E. caproni and Echinostoma trivolvis cercariae in Biomphalaria glabrata. Int J Parasitol. (1998) 28:595-7. doi: 10.1016/S0020-7519(97)00206-3

191. Jeyarasasingam U, Heyneman D, Lim H-K, Mansour N. Life cycle of a new echinostome from Egypt, Echinostoma liei sp. nov.(Trematoda: Echinostomatidae). Parasitology. (1972) 65:203-22. doi: 10.1017/S0031182000044991

192. Jourdane J, Mounkassa J, Imbert-Establet D. Influence of intramolluscan larval stages of Echinostoma liei on the infectivity of Schistosoma mansoni cercariae. J Helminthol. (1990) 64:71-4. doi: 10.1017/S0022149X00011925

193. Barus V, Moravec F, Rysavý B, Yousif F. Antagonism of Echinostoma revolutum against Schistosoma mansoni in the snail Biomphalaria alexandrina. Fol Parasitol. (1974) 21:143.

194. Fried B, Schmidt KA, Sorensen RE. In vivo and ectopic encystment of Echinostoma revolutum and chemical excystation of the metacercariae. $J$ Parasitol. (1997) 83:251-4. doi: 10.2307/3284449 
195. Hsu KC, Lie KJ, Basch PF. The life history of Echinostoma rodriguesi sp. n. (Trematoda: Echinostomatidae). J Parasitol. (1968) 54:333-9. doi: $10.2307 / 3276946$

196. Maldonado A Jr, Vieira G, Lanfredi R. Echinostoma luisreyi n. sp. (Platyhelminthes: Digenea) by light and scanning electron microscopy. $J$ Parasitol. (2003) 89:800-8. doi: 10.1645/GE-3095

197. Joe LK, Basch PF, Heyneman D, Fitzgerald F. Antagonism between two species of echinostomes (Paryphostomum segregatum and Echinostoma lindoense) in the snail Biomphalaria glabrata. Z Parasitenkund. (1968) 30:117-25. doi: 10.1007/BF00259720

198. Lo C-T. Echinostoma macrorchis: life history, population dynamics of intramolluscan stages, and the first and second intermediate hosts. J Parasitol. (1995) 81:569-76. doi: 10.2307/3283855

199. Lie KJ, Basch PF, Hoffman MA. Antagonism between Paryphostomum segregatum and Echinostoma barbosai in the snail Biomphalaria straminea. J Parasitol. (1967) 53:1205-9. doi: 10.2307/3276681

200. Muñoz-Antoli C, Trelis M, Toledo R, Esteban J. Infectivity of Echinostoma friedi miracidia to different snail species under experimental conditions. $J$ Helminthol. (2006) 80:323-5.

201. Jourdane J, Kulo S. [Experimental study of the life cycle of Echinostoma togoensis n. sp., a larval parasite of Biomphalaria pfeifferi in Togo (author's transl)]. Ann Parasitol Hum Comp. (1980) 56:477-88. doi: 10.1051/parasite/1981565477

202. McCarthy A. The influence of second intermediate host species on the infectivity of metacercarial cysts of Echinoparyphium recurvatum. J Helminthol. (1999) 73:143-5. doi: 10.1017/S0022149X99000219

203. Flores VR, Semenas LG, Veleizán AA. Larval digenean community parasitizing the freshwater snail, Biomphalaria peregrina (Pulmonata: Planorbidae), from a temporary pond in Patagonia, Argentina. J Parasitol. (2010) 96:652-6. doi: 10.1645/GE-2040.1

204. Malek EA. Natural infection of the snail Biomphalaria obstructa in Louisiana with Ribeiroia ondatrae and Echinoparyphium flexum, with notes on the genus Psilostomum. Tulane Stud Zool Bot. (1977) 19:131-6.

205. Spatz L, Cappa SMG, de Núñez MO. Susceptibility of wild populations of Biomphalaria spp. from neotropical South America to Schistosoma mansoni and interference of Zygocotyle lunata. J Parasitol. (2012) 98:12915. doi: 10.1645/GE-3002.1

206. Nassi H. [Data on the life cycle of Ribeiroia marini guadeloupensis n. ssp., a trematode sterilizing Biomphalaria glabrata in Guadeloupe]. Acta Trop. (1978) 35:41-56.

207. Pinto H, Jadin R, Orlofske S, Johnson P, Melo A. Biomphalaria straminea (Mollusca: Planorbidae) as an intermediate host of Ribeiroia sp.(Trematoda: Psilostomidae) in Brazil. J Parasitol. (2013) 99:914-8. doi: 10.1645/GE3214.1

208. Pinto H, Melo A. Biomphalaria straminea and Biomphalaria glabrata (Mollusca: Planorbidae) as new intermediate hosts of the fish eyefluke Austrodiplostomum compactum (Trematoda: Diplostomidae) in Brazil. J Parasitol. (2013) 99:729-33. doi: 10.1645/12-13.1

209. Barcante TA, de Paiva Barçante JM, Dias SRC, dos Santos Lima W. Angiostrongylus vasorum (Baillet, 1866) Kamensky, 1905: emergence of third-stage larvae from infected Biomphalaria glabrata snails. Parasitol Res. (2003) 91:471-5. doi: 10.1007/s00436-003-1000-9

210. Pereira C, Martins-Souza R, Coelho P, Lima W, Negrao-Corrêa D. Effect of Angiostrongylus vasorum infection on Biomphalaria tenagophila susceptibility to Schistosoma mansoni. Acta Trop. (2006) 98:224-33. doi: 10.1016/j.actatropica.2006.05.002

211. Ubelaker JE, Bullick GR, Caruso J. Emergence of third-stage larvae of Angiostrongylus costaricensis Morera and Cespedes 1971 from Biomphalaria glabrata (Say). J Parasitol. (1980) 66:856-7. doi: 10.2307/ 3280689

212. Tunholi-Alves VM, Tunholi VM, Lustrino D, Amaral LS, Thiengo SC, Pinheiro J. Changes in the reproductive biology of Biomphalaria glabrata experimentally infected with the nematode Angiostrongylus cantonensis. J Invert Pathol. (2011) 108:220-3. doi: 10.1016/j.jip.2011.08.009

213. Iwanaga Y. Comparative studies on the development of larval Angiostrongylus cantonensis in Puerto Rican and Brazilian Biomphalarla Snails. Japan J Trop Med Hyg. (2002) 30:365-9. doi: 10.2149/tmh1973.30.365

214. Ibrahim M. Prevalence and intensity of Angiostrongylus cantonensis in freshwater snails in relation to some ecological and biological factors. Parasite. (2007) 14:61-7. doi: 10.1051/parasite/2007141061

215. Yousif F, Lämmler G. The suitability of several aquatic snails as intermediate hosts for Angiostrongylus cantonensis. Z Parasitenkund. (1975) 47:20310. doi: 10.1007/BF00418203

216. Katakura K, Oku Y, Kamiya M, Ohbayashi M. Development of the mesenteric metastrongylid Angiostrongylus siamensis, in Biomphalaria glabrata, an experimental intermediate host. Jpn J Parasitol. (1981) 30:23-30.

217. Moraes Jd, Silva MPNd, Ohlweiler FP, Kawano T. Schistosoma mansoni and other larval trematodes in Biomphalaria tenagophila (Planorbidae) from Guarulhos, São Paulo State, Brazil. Rev Inst Med Trop São Paulo. (2009) 51:77-82. doi: 10.1590/S0036-46652009000200004

218. Lima W, Guimaraes M, Lemos I. Occurrence of Angiostrongylus vasorum in the lungs of the Brazilian fox Dusicyon vetulus. J Helminthol. (1994) 68:87. doi: 10.1017/S0022149X00013547

219. Conboy G. Natural infections of Crenosoma vulpis and Angiostrongylus vasorum in dogs in Atlantic Canada and their treatment with milbemycin oxime. Vet Rec. (2004) 155:16-8. doi: 10.1136/vr.155.1.16

220. Morley N. Aquatic molluscs as auxiliary hosts for terrestrial nematode parasites: implications for pathogen transmission in a changing climate. Parasitology. (2010) 137:1041-56. doi: 10.1017/S0031182010000016

221. Slom TJ, Cortese MM, Gerber SI, Jones RC, Holtz TH, Lopez AS, et al. An outbreak of eosinophilic meningitis caused by Angiostrongylus cantonensis in travelers returning from the Caribbean. New Eng J Med. (2002) 346:66875. doi: 10.1056/NEJMoa012462

222. Tunholi-Alves VM, Tunholi VM, Pinheiro J, Thiengo SC. Effects of infection by larvae of Angiostrongylus cantonensis (Nematoda, Metastrongylidae) on the metabolism of the experimental intermediate host Biomphalaria glabrata. Exp Parasitol. (2012) 131:143-7. doi: 10.1016/j.exppara.2012.03.003

223. Loker E, Moyo H, Gardner SL. Trematode-gastropod associations in nine non-lacustrine habitats in the Mwanza region of Tanzania. Parasitology. (1981) 83:381-99. doi: 10.1017/S0031182000085383

224. Simoonga C, Utzinger J, Brooker S, Vounatsou P, Appleton CC, Stensgaard AS, Olsen A, Kristensen TK. Remote sensing, geographical information system and spatial analysis for schistosomiasis epidemiology and ecology in Africa. Parasitology. (2009) 136:1683-93. doi: 10.1017/S0031182009006222

225. Guo JY, Xu J, Zhang LJ, Lv S, Cao CL, Li SZ, et al. Surveillance on schistosomiasis in five provincial-level administrative divisions of the People's Republic of China in the post-elimination era. Infect Dis Poverty. (2020) 9:136

226. Xu J, Li SZ, Zhang LJ, Bergquist R, Dang H, Wang Q, et al. Surveillancebased evidence: elimination of schistosomiasis as a public health problem in the Peoples' Republic of China. Infect Dis Poverty. (2020) 9:63. doi: 10.1186/s40249-020-00676-5

Conflict of Interest: The authors declare that the research was conducted in the absence of any commercial or financial relationships that could be construed as a potential conflict of interest.

Copyright (c) 2021 Habib, Lv, Rollinson and Zhou. This is an open-access article distributed under the terms of the Creative Commons Attribution License (CC BY). The use, distribution or reproduction in other forums is permitted, provided the original author(s) and the copyright owner(s) are credited and that the original publication in this journal is cited, in accordance with accepted academic practice. No use, distribution or reproduction is permitted which does not comply with these terms. 